\title{
The Christianisation of Latin Europe as Seen by Medieval Arab-Islamic Historiograpfiers
}

\author{
Daniel König*
}

\begin{abstract}
The article aims at defining what Arab Muslims of the crusading period knew about the conversion of Latin Europe to Christianity through an analysis of Arabic-Islamic sources written up to the fourteenth century. Whereas Christianity seems to have interested the first generations of Muslims mainly as a theological phenomenon, the emergence of more comprehensive forms of Muslim historiography led to the creation of Arabic texts dealing with the formation of Christianity. The latter's primary focus lay on the Christianisation of the Roman Empire. However, the premises that set the stage for the emergence of Latin-Christian Europe (Roman hegemony in the West, 'period of migrations', Romano-Germanic successor states) do not seem to have been fully understood until translated Latin sources were diffused in the Arabic-Islamic world. Hence, most references to the Christianisation of the post-Roman peoples of Western Europe are short and out of chronological context. Continuity is only fully acknowledged in the case of the papacy.
\end{abstract}

Writing in the twelfth century, the Genoese historiographer, Cafaro (d. 1166), gave the following account of two 'Saracens' who approached the patriarch of Jerusalem and the papal legate, after the Genoese had wrought destruction around the city of Caesarea in Palestine in 1101: ${ }^{1}$

${ }^{1}$ Cafaro, Annales Ianuenses, a. 1101: 13, translated by the author. Muslim criticism of Christian violence is also documented in other sources, some of them dating back to the ninth century, cf. Kedar, Crusade and Mission: 97-98.

*German Historical Institute, 8 Rue du Parc Royal, Paris, France. E-mail: dkoenig@dhiparis.fr

The Medieval History Journal, 12, 2 (2009): 431-472

SAGE Publications Los Angeles/London/New Delfi/Singapore/Wasfington DC DOI: $10.1177 / 097194580901200211$ 
Meanwhile two Saracens came out of the city and spoke to the patriarch and the legate of the Roman Curia in the following way: 'O lords, who you are scholars and teachers of the Christian law, why do you teach your kin to kill us and to take away our land, if it is written in your law that no one should kill anyone else bearing the likeness of your God nor take away his property? Because if what is written in your law is so and we bear the likeness of your God, then you act contrary to the law.'

Interim vero Saraceni duo de civitate exierunt, et cum patriarcha et Romane curie legato taliter locuti fuerunt: ' $O$ domini, vos qui estis magistri et doctores christiane legis, quare precipitis vestratibus, ut nos interficiant et terram nostram tollant, cum in lege vestra scriptum sit, ut aliquis non interficiat aliquem formam Dei vestri habentem, vel rem suam tollat? Et si verum est, quod in lege vestra scriptum sit hoc, et nos formam Dei vestri habemus; ergo contra legem facitis.'

Cafaro's was one of several texts written between the twelfth and the fourteenth centuries which bear testimony to crusaders being reproached by Muslims for resorting to violence, although this transgressed the precepts formulated by Jesus, handed down through generations of Christians. ${ }^{2}$ Such texts could be read as evidence that some Muslims questioned the ideological legitimacy of the crusades. ${ }^{3}$ However, what medieval Muslims saw in the crusades is not of primary interest here. Rather this article sets out to analyse how medieval Muslim historiographers, writing in Arabic, explained that the European peoples attacking them in the Middle East, the Iberian Peninsula, several Mediterranean islands and North Africa had become Christians in the first place.

Such an analysis poses many problems since it entails understanding what these historiographers knew about a whole range of subjects relating to the Christianisation of Latin Europe: the development and diffusion of early Christian beliefs within the Roman Empire of the first century,

${ }^{2}$ For further reading, ibid: $97-99$.

${ }^{3}$ However, not all Muslims regarded the crusades as an essentially religious phenomenon: Ibn al-Ațīr, al-kāmil fī-t-tārīh , vol. X, AH. 491: 272-73, attributes the idea of embarking on a crusade to Jerusalem to Roger of Sicily who needed to divert European expansionism to the Middle East in order to maintain his relations with North African Muslim allies and his position as the ruler of Sicily. Ibn Haldūn, tārīh, vol. I: 451, interprets the crusades as a struggle for maritime hegemony in the Mediterranean. Cf. Ibn Khaldûn, The Muqaddimah II, 36-40.

- The Medieval History Journal, 12, 2 (2009): 431-472 
the waves of persecution which followed and took place at irregular intervals until the beginning of the fourth century, the conversion of Constantine, the means successive Christian emperors adopted to promote Christianity during the fourth and fifth centuries, the so-called period of migrations from the end of the fourth to the end of the sixth century, the ensuing Christianisation of Germanic peoples as well as the later expansion of Christianity among the peoples of the Slavic and Nordic world up to the beginning of the second millenium.

Events, processes, causes and motives associated with the 'conversion' of Latin Europe have been extensively analysed elsewhere. ${ }^{4}$ Here, it would suffice to state that an analysis of conversions in a late antique and early medieval context serves to explain how fundamental aspects of Latin-Christian civilisation came into being. In view of the rivalry, the confrontations, but also the compromises that characterised the relationships between representatives of 'Latin Christianity' and 'the ArabIslamic world' in the Middle Ages, ${ }^{5}$ the Christianisation of Europe must be regarded as a historical process of utmost importance. It substantially shaped intercultural relations across the Mediterranean basin and beyond - on every social level and for centuries to come. Therefore, the exercise of analysing medieval Arab-Islamic perceptions of this process is not without relevance, especially with regard to the recent boom of public and scholarly debates about the relationship, both historical and contemporary, between 'Islam' and 'the West'. So far, Bernard Lewis has written the most influential book on the subject of what the medieval and early modern Islamic world 'knew' about European Christianity. In a chapter of his book, The Muslim Discovery of Europe, Lewis observes in passing that medieval Muslim scholars had obtained some knowledge about early Christian history, Christian beliefs and practices, as well as

\footnotetext{
${ }^{4}$ For further reading: cf. Harnack, Die Mission und Ausbreitung des Christentums in den ersten drei Jahrhunderten; MacMullen, Christianizing the Roman Empire (A.D. 100-400); Praet, 'Explaining the Christianization of the Roman Empire'; König, Bekehrungsmotive. Untersuchungen zum Christianisierungsprozess im römischen Westreich und seinen romanisch-germanischen Nachfolgern (4.-8. Jh.); Dumézil, Les racines chrétiennes de l'Europe. Conversion et liberté dans les royaumes barbares, Ve-VIII siécles; Padberg, Die Christianisierung Europas im Mittelalter.

${ }^{5}$ For the sake of convenience, the terms 'Middle Ages' and 'medieval' are used for both the Latin-Christian and the Arab-Islamic sphere, even though their use is disputed when dealing with the history of the non-European world.
} 
some of the different schools and sects. In addition, he devotes some space to medieval Arab-Islamic descriptions of the papacy. But apart from this, his chapter is based primarily on a selection of Ottoman sources which the author implicitly regards as representative of a prevalent 'Islamic attitude' towards European Christianity. By focussing on examples that highlight Muslim ignorance of and arrogance towards LatinChristian Europe, Lewis depicts and thus strengthens the widespread image of an Islamic civilisation in entirety, one which viewed European Christians as infidels who needed to be subdued to Islam. ${ }^{6}$ Prone to generalisation, Lewis thus over-emphasises certain 'Muslim' attitudes towards European Christianity and largely ignores the existence of multiple perspectives and opinions, which themselves evolved processually with the formation of the medieval Arab-Islamic world and its subsequent access to different sources of information. ${ }^{7}$

An analysis of what medieval Arab-Islamic historiographers documented about the Christianisation of Europe proves, on the one hand, that-within a historical context not marked by descriptions of LatinChristian aggression, for example, during the Reconquista or the crusades-Latin Christianity could be dealt with neutrally and even favourably by Arab-Islamic historiographers. On the other hand, such an analysis also demonstrates that arrogance, rivalry, lack of interest, etc., are only three among many factors that shaped the ways in which Arab-Islamic perceptions of Latin Christianity were formed; the concerned author's access to high quality information (or the lack of it) played an important role as well.

Needless to say, lines of communication between the Latin-Christian and the Arab world had already existed before the Muslim expansion in the regions around the Mediterranean during the seventh and eighth centuries. However, clues to such contacts are to be found, not in Arabic sources, but only in contemporary Latin texts that deal with pilgrims, merchants and other travellers from Western Europe; it is not easy to identify who the 'Saracens' mentioned in these sources were. ${ }^{8}$ It is even more difficult to estimate the extent to which pre-Islamic Arabs were

${ }^{6}$ Lewis, The Muslim Discovery of Europe: 171-73.

${ }^{7}$ Ibid: : $171-85$.

${ }^{8}$ Hieronymus, ep. 129, 4: 169-70; Victor Tonnenensis, Chronica, a. 512: 195; Iohannes Biclarensis, Chronica, a. 575, 3: 214; Antoninus Placentinus, Itinerarium; Rotter, Abendland und Sarazenen: 10, 12-31, 131-38. For references to commercial contacts

- The Medieval History Journal, 12, 2 (2009): 431-472 
able to differentiate between Latin Christians and Christians from other parts of a Mediterranean world dominated by several forms of Christianity. The Arab-Islamic expansion certainly facilitated contact: contemporary Latin and later Arabic sources suggest repeatedly that the conquerors regularly encountered Christians or Christian cult objects in territories habitually ascribed to the cultural orbit of Latin Christianity. ${ }^{9}$ After the initial force of expansion had phased out, exchanges between Latin Christianity and the Arab-Islamic world were numerous. ${ }^{10}$ In view of these

between the Latin West and the Middle East, see: Gregorius Turonensis, Libri decem VII, 29: 347 and In gloria confessorum 64: 336.

${ }^{9}$ In 653, Pope Martin I wrote a letter in which he vigourously denied accusations by the Byzantine government of having sent clerics with messages and money to the expanding 'Saracens'; cf. Martinus papa, ep. 14 ad Theodorem: 199A. An early Latin text and later Arabic sources mention or cite a peace treaty ascribed to the first governor of Muslim Spain, 'Abdu-l-'Azīz bin Mūsā, and the Visigothic noble, Theodemir, in which the former grants freedom of worship to the Christian community under the latter's jurisdiction. The treaty is mentioned in the chronicle of 754 (Chronica hispana $\S 74: 354$ ), and given in full text in the Tarșī' al-ahbār by al- 'Udrīi in the eleventh century, the Bugyat al-multamis by aḍ-Dabbī in the eleventh century and the kitāb ar-rauḍ al-mi 'țār by al-Himyarī, dating probably from the fifteenth century; cf. Molina, 'Tudmīr': 628-30, who questions the authenticity of the document, which nevertheless depicts plausibly, how conquerors and conquered found a suitable arrangement. Latin and Arabic sources, dating from the ninth but referring to the eighth century, describe Muslim raids in Sardinia and the Frankish kingdom during which churches were pillaged and occasionally, even destroyed: Ibn 'Abdu-1-Hakam, futūh mișr wa ahbārihā: 209, describes how Muslim raiders of Sardinia find the hidden treasures of the island's populace concealed in a church. Several Latin sources dating from the eighth and ninth century (Fredegar Continuator, Chronicarum continuationes $\S 13$ : 175; Gesta abbatum Fontanellensium $\S$ 9: 29; Annales Mettenses priores, a. 732: 27) report that the Church of Saint Hilarius at Poitiers was burnt during a 'Saracen' raid. Also interesting is a remark by al-Bālādurī, kitāb futūh al-buldān § 275: 235, who mentions that Muslim raiders of Sicily found 'idols of gold and silver studded with pearls' which Mu'āwiya bin Ab̄̄ Sufyān sent to India in order to receive a higher price for them. Possibly the raiders encountered Roman-Byzantine art work or interpreted Christian cult objects as pagan.

${ }^{10}$ Note, for example, that Christian slaves and captives were exported to the southern shores of the Mediterranean; cf. Codex Carolinus § 59: 585; Bernardus monachus, Itinerarium factum in loca sancta 4, vol. 121: 569-70; Chronicon Moissiacense, a. 715: 290; Ibn Hurradad̄bih: kitāb al-masālik wa-l-mamālik: 92; Ibn al-Faqīh al-Hamad̄ān̄̄, muhtașar kitāb al-buldān: 84; Ibn Hauqal, kitāb șūrat al-ard: 110. Arab-Islamic jurists expressed their opinions about the legitimacy of attacking Christian merchant ships trading with Muslim North Africa; cf. Talbi, 'Intérêt des oeuvres juridiques traitant de la guerre pour l'historien des armées médiévales ifrikiyennes': 290-91. Diplomatic exchanges

The Medieval History Journal, 12, 2 (2009): 431-472 
contacts, it is inconceivable that members of Arab-Islamic communities could have remained ignorant of the fact that Western Europe was dominated by Christianity. An Arabic translation of the Psalter produced in ninth century Córdoba, ${ }^{11}$ al-Ya 'qūbī's (ninth century) quotations from the gospels, ${ }^{12}$ a detailed refutation of the gospels by the Cordovan author Ibn Hazm (d. 1064) as well as several biblical texts in Arabic clearly demonstrate that scholars of the post-expansion period had access to basic Christian texts. ${ }^{13}$ Thus, there existed a sufficient number of contacts between the Arab-Islamic and the Latin-Christian world as to enable Muslim scholars to acquire information about Latin Christianity and, eventually, the history of its formation.

A text in which a medieval Muslim author writing in Arabic explicitly answers the question as to how Latin Europe became Christian has, however, yet to be found. Instead, Arab-Islamic sources of the Middle Ages contain several more or less elaborate accounts of the Christianisation of the Roman Empire as well as miscellaneous information about the Christianity and, less often, the Christianisation of a number of post-Roman peoples. The Christianisation of the Roman Empire is dealt with in most works of universal history dealing with the pre-Islamic past, such as the

occurred from the eighth century onwards; cf. Borgolte, Der Gesandtenaustausch der Karolinger mit den Abbasiden und mit den Patriarchen von Jerusalem; al-Ḥağǧ̄̃ 2004, 'a lāqāt ad-diblūmāsiya al-andalusiyya ma' Ūrubbā āl-g̉arbiya hilāl al-muddat al-ummawiyya (138-366 AH/755-976AD), aš-Šaih, dawlat al-Faranğa wa 'alāqātihā bi-1-Umawiyyīn fī-l-Andalus: hattā awāhir al-qarn al- 'ašir al-mīlādī (138-366 AH/755-976 AD). Members of both communities lived side by side under Islamic rule in Sicily and the Iberian peninsula. The sources document mixed marriages (cf. Eulogius, Memoriale Sanctorum II, cap. VIII, 3: 409; cap. VIII, 9: 412; cf. Millet-Gérard, Chrétiens mozarabes et culture islamique dans l'Espagne des VIII ${ }^{e}-I X^{e}$ siècles: 31; Wolf, Christian Martyrs in Muslim Spain: 26, 32; Ibn Hauqal, kitāb șürat al-ard: 129) and Christians who held important posts at the Cordovan court in the ninth and tenth centuries (cf. Iohannis abbas s. Arnulfi, Vita Iohannis Gorziensis § 128: 374; Ibn Ḥayyān al-Qurțub̄̄, al-muqtabis min abnā' ahl al-Andalus: 138, 142; Ibn Ḥayyān, Crónica de los emires Alhakam I y 'Abdarraḥmān II [Al-muqtabis II-1]: 66 (107r)), etc.

${ }^{11}$ Hafs le Goth, Le Psautier mozarabe de Hafs le Goth.

${ }^{12}$ al-Ya'qūbī, tārīh al-Ya'qū bī, vol. I: 57-68.

${ }^{13}$ Cf. Ibn Hazm, kitāb al-fișal fì-l-milal wa-l-ahwā' wa-n-nihal: 45-46; for further read-ing: cf. Ljamai, Ibn Hazm et la polémique islamo-chrétienne dans l'histoire de l'islam; Behloul, Ibn Hazms Evangelienkritik. Eine methodische Untersuchung. For literature on Arabic translations of biblical texts, see Kahle, Die arabischen Bibelübersetzungen; Graf, Geschichte der christlichen arabischen Literatur, vol. I; Henninger, 'Arabische Bibelübersetzungen vom Frühmittelalter bis zum 19. Jh'.

- The Medieval History Journal, 12, 2 (2009): 431-472 
works of al-Ya'qūbī (ninth century), aț-Ṭabari (d. 923), al-Bīrūn̄̄ (d. 1050), Ibn al-Ațīr (d. 1233), Abū-l-Fidā' (d. 1331) and Ibn Haldūn (d. 1406). It is also treated in geographical and ethnographical treatises that pay attention to the history of certain localities and peoples, as written by Ibn Hurradadbih (ninth century), Ibn al-Faqīh al-Hamadānī (tenth century), Ibn Rustah (d. after 913), al-Isțahrī (d. 951), Ibn Hauqal (tenth century), al-Mas 'ūd̄̄ (d. 956), al-Bakrī (d. 1094), Ibn Sa'īd al-Mag̉ribī (d. 1286) and Abū-1-Fidā' (d. 1331). More specialised historiographical works, especially works concerned with regional or dynastic affairs, mostly ignore the subject, ${ }^{14}$ an exception being a treatise on the history of science by Șā'id al-Andalusī (d. 1070). Theological and polemical writings dealing with the Christian religion as such may touch on certain historical developments of Christian dogma or institutions such as the papacy, but mainly focus on Christianity as a theological system without delving into historical details or even attempting to provide an overview of Christian expansion in Roman times. ${ }^{15}$

The Christianisation of the post-Roman Latin West, in turn, is rarely treated in works of universal history. If at all, only the Christianisation of the Visigoths and the Franks is mentioned. Regional and dynastic histories may provide information, especially if they address relations with Latin-Christian Europe. More attention to the post-Roman peoples of Latin Europe is paid instead by geographers and ethnographers attempting to give an exhaustive description of the world's northern inhabitants. Theological and polemical writings neglect the subject. Finally, miscellaneous sources without any apparent connection to the history of Christianisation, such as a work on occidental Arabic poetry by Ibn Dihya (d. 1235), may contain references of interest. Thus, information about several aspects of the rise of Christianity in Latin Europe may be found in medieval Arabic literature, but never in the form of a coherent theory such as the one formulated, for example, by the early ideologue of Islamic fundamentalism in the twentieth century, Sayyid Quț. ${ }^{16}$ Because of the dispersed nature of these references, it is necessary to present what

${ }^{14}$ E.g., the works of Ibn 'Abdu-l-Ḥakam (d. 871), al-Balādurī (d. 892), Ibn Hayyān (d. 1076), Ibn Wāṣil (d. 1298) and Ibn 'Idāāī al-Marrākuš̄i (fourteenth century).

${ }^{15}$ E.g., the works by Abū 'Īsā al-Warrāq (ninth century), Ibn Hazm (d. 1064), ašŠahristānī (d. 1153), al-Imām al-Qurțubī (thirteenth-fourteenth centuries) and Ibn Taymiyya (d. 1328).

${ }^{16}$ Shepard, Sayyid Qutb and Islamic Activism: 2-5, 20-21, 282, 291-93. Quṭ's main theme is the corruption of the Christian message as soon as the late antique and medieval

The Medieval History Journal, 12, 2 (2009): 431-472 
medieval Arab-Islamic scholars knew in thematic order rather than in chronological sequence of their writing.

\section{The Christianisation of the Roman Empire}

It is common knowledge that Christianity forms an important part of the Islamic heritage. Jesus and Christians, in general, find frequent mention in the Qur'ān. ${ }^{17}$ According to Islamic tradition, the prophet was not only acquainted with Christians, but even akin to Waraqa bin Naufal, a preIslamic convert to Christianity considered as an expert on Jewish and Christian scriptures. ${ }^{18}$ Judging from the Qur'ānic text, it seems however, that, for the early Muslims, Christianity was more important as a spiritual and theological rather than a historical phenomenon. In opposition to the gospels and the acts of the apostles that explicitly depict the historical, political and social setting of early Christianity within the Eastern part of the Roman Empire, the Qur'ān provides no chronological framework whatsoever. ${ }^{19}$ The story of the Seven Sleepers of Ephesos, to which the Qur'ān dedicates an entire sura (18: al-kahf), may serve as a striking

church entered secular power play. Cf. König, 'Der Nutzen von Außenperspektiven': 207-08.

${ }^{17}$ For further reading: Zwemer, The Moslem Christ. An Essay on the Life, Character, and Teachings of Jesus Christ According to the Koran and Orthodox Tradition; Bachmann, Jesus im Koran; Khalidi, The Muslim Jesus: Sayings and Stories in Islamic Literature; Qazzī, nașārā al-Qur' ān wa masīḥ̄yūhu, Parrinder, Jesus in the Qur'ān; Antequera, Jesús en el Corán; Qazzī, Masīh al-Qur'ān wa Masīh al-muslimīn, Arsel, Juden und Christen im Koran; Bazargan, Und Jesus ist sein Prophet: Der Koran und die Christen; Çinar, Maria und Jesus im Islam.

${ }^{18}$ Cf. Ibn Hišām, as-sīra an-nabawiya, vol. I: 222, 238; al-Buhāarī, șaḥ̄ḥ al-Buhārī̄. L'Authentique d'al-Bukhârî, vol. I, cap. 3: 8-9; cf. Ḥusain, Waraqa Ibn Naufal: mubaššir ar-rasūl. 'așruhū, hayātuhū, ši 'ruhū.

${ }^{19}$ Jesus is never mentioned in a historical, i. e. Roman context, cf. Qur'ān 2: 87, 116, 136,$253 ; 3: 3,45-52,55,59,84 ; 4: 157,163,171-72 ; 5: 17,46,72-73,75,78,110-18$; $6: 85 ; 9: 30-31 ; 10: 68 ; 17: 111 ; 18: 4 ; 19: 30-35,88,92 ; 21: 26-27 ; 23: 50,91 ; 25: 2$; $33: 7 ; 37: 151-52 ; 39: 4 ; 42: 13 ; 43: 57,61,63,81 ; 57: 27 ; 61: 6,14 ; 72: 3$. Later historiographers, however, reinterpreted the Qur'ān according to their knowledge about early Christian and Roman history: Cf. al-Mas' 'ūdī, murūğ ad-dahab II,300, § 722: 35; al-Mas ‘ūdī, Les Prairies d'Or II,300, § 722: 271, who interprets passages of sura 36: 1321, as referring to Peter, Paul and Simon the Magian.

- The Medieval History Journal, 12, 2 (2009): 431-472 
example: The story of seven Christians fleeing Roman persecution is set in the ruling period of the emperor Decius by most medieval Latin texts that mention the legend. ${ }^{20}$ The Qur'ān, in contrast, only alludes to the persecution without giving any information as to the place, time or historical circumstances of the event. ${ }^{21}$ The fact that later Muslim historiographers refer to the early Muslim traditionist Ibn Ishāa (d. ca. 767) when reporting about early Christian and early ecclesiastical history, ${ }^{22}$ proves that Christianity as a historical phenomenon became more important as soon as more complex and more comprehensive forms of documenting history were developed among Muslim scholars. ${ }^{23}$

Among the earliest Arab-Islamic works dealing with the Christianisation of the Roman Empire is the universal history of al-Ya 'qūbī (ninth century). Al-Ya 'qūbī devotes a chapter to the life of Jesus, which is based primarily on the gospels. Here, he mentions the apostles, but more or less bypasses the Roman context, only providing scarce information about the missionary activity of Paul, who allegedly preached Christianity to a Roman ruler. ${ }^{24}$ In his chapter on Roman rulers, however, the author correlates Jesus' birth with the ruling years of the Emperor Augustus. ${ }^{25}$ This is followed by a list of pagan Roman emperors from Augustus to Constantine, which mentions the cult of the emperors in connection with Vespasian but completely ignores the persecutions. ${ }^{26}$ At the end of this list, al-Ya 'qūbī devotes several paragraphs to Greek and Roman religious

${ }^{20} \mathrm{Cf}$. Heinzelmann. 'La réécriture hagiographique dans l'œuvre de Grégoire de Tours' 59-68, with further literature.

${ }^{21}$ Qur'ān 18: 09-26; cf. Jourdan, de Saroug and Ibn 'Abbās, La tradition des Sept Dormants: une rencontre entre chrétiens et musulmans.

${ }^{22}$ E.g. aț-Ṭabari, tārīh ar-rusul wa-l-mulūk, Vol. I: 602; Ibn Haldūn, tārīhn, vol. II, 294-95.

${ }^{23}$ On the development of early Arab-Islamic historiography see: ad-Dūrī, 'Abdu-1'Azīz. 'naš' at at-tārīh 'ind al-'arab wa tațawwuruhu hilāl al-qurūn at-talāta al-ūlā li-1hiğra': 13-51; Khalidi. Arabic Historical Thought in the Classical Period, Schoeler. Charakter und Authentie der muslimischen Überlieferung über das Leben Mohammeds: 166-69; Donner. Narratives of Islamic Origins. The Beginnings of Islamic Historical Writing: 275-90; Schoeler, Gregor, The Genesis of Literature in Islam. From the Aural to the Read.

${ }^{24}$ al-Ya'qūbī, tārīh $a l-Y a$ 'qūbì, vol. I: 56-68, especially 67-68.

${ }^{25}$ Ibid: : 126.

${ }^{26}$ Ibid.: 126-28, especially 127. 
philosophy in pre-Constantinian times. Among the schools of thought mentioned are the Sabaeans, who believed in a creator and in certain prophets such as Hermes Trismegistos; the Sophists, who called everything into question; the Atheists, who negated the existence of God and revelation; the Aristotelians, who approached the world from a scientific point of view; as well as others. ${ }^{27}$

In the subsequent chapter devoted to the Christianised rulers of the Romans, al-Ya'qūbī deals with the conversion of Constantine: in war with an unnamed people, Constantine had a vision in his sleep which made him decorate his lance with the sign of the cross. The resulting victory provided the impetus for his conversion to Christianity. ${ }^{28}$ Following this, Constantine invited 318 bishops, including the patriarchs of Alexandria, Rome, Antiochia and Constantinople, to Nicaea in order to find a solution to different quarrels among Christians which impeded his search for spiritual truth. Several details are provided about the subjects discussed and the positions taken during the council, thus throwing light on several Christian disputes (not all of them discussed in Nicaea) concerning the nature of Christ, the relationship between God, the Father, and God, the Son, as well as the status of Mary. In al-Ya 'qūbī's account, Constantine's reign is followed by the rule of Julian, whose apostasy is not mentioned. Julian, in turn, is (incorrectly) succeeded by Decius, one of the persecutors. Al-Ya'qūbī erroneously attributes the reappearance (as opposed to the flight) of the Seven Sleepers of Ephesos to the latter's rule. The chapter proceeds with a list of Roman rulers, mentioning the oecumenical councils of Constantinople I, Ephesos and Constantinople II, and quoting the Nicaean creed in Arabic. ${ }^{29}$ Later Arab-Islamic historiographers more or less followed the same pattern, occasionally elaborated on certain subjects, but did not necessarily improve on the account of al-Ya'qūbī. The Roman setting of Jesus' life is treated more extensively by at-Tabari and Ibn Haldūn, whereas al-Mas 'ūdi, al-Bīrūnī, al-Bakrī, Ibn al-Ațīr as well as Abū-l-Fidā' do not essentially provide more information. ${ }^{30}$

${ }^{27}$ Ibid.: $128-32$.

${ }^{28}$ Cf. Lactantius, De mortibus persecutorum 44, 5f.: 127; Eusebius, Vita Constantini I, 28-32: 25-27.

${ }^{29}$ al-Ya'qūbī, tārīh al-Ya'qūbū, vol. I: 132-35.

${ }^{30}$ aț-Tabarī, tārīh ar-rusul wa-l-mulūk, vol. I: 604-05; Ibn Haldūn, tārīh, vol. II: 291-95, 297, 408, 432; al-Mas 'ūdī, murū ̌̆ a $\underline{d}-\underline{d} a h a b$ II, 297-99, § 719-21: 34-35 (Arabic ed.), 270-71 (French transl.); al-Bīrūn̄i, atāar al-bāqiya: 29; al-Bakrī, kitāb al-masālik wa-l-mamālik § 485: 306-07; Ibn al-Ațīr, al-kāmil fì-t-tārīh, vol. I: 307-23, copies aț-Ṭabarī; Abū-1-Fidā', tārīh: 62.

- The Medieval History Journal, 12, 2 (2009): 431-472 
Knowledge about the pre-Christian religiosity of the Roman Empire certainly did not improve in comparison to al-Ya 'qūbī. The majority of later Muslim historiographers refer to the pre-Christian Romans as 'Sabaeans', 'idolaters' or 'Magians', and only rarely specify Roman variations of paganism. Ibn al-Atīir and Abū-l-Fidā' define 'Sabaean idolatry' practiced by the Romans as the veneration of seven planets, among these Venus (az-Zahra). Many historiographers refer to pagan architecture, in particular to temples built by the Emperors Hadrian and Severus in Jerusalem and Alexandria which were dedicated to Venus and 'the deity' (al-ilāha) respectively. Ibn Haldūn additionally refers to the cult of emperors, which he attributes to an unnamed successor of Tiberius. Further references to pre-Christian religiosity only concern the cult of idols. ${ }^{31}$ Thus, among Arab-Islamic historiographers, knowledge of pre-Christian Roman religion did not grow with time. Instead, stereotypical concepts and terminology that all monotheistic religions developed to designate the 'unbelieving' adherents to polytheism became rather dominant in the course of the centuries. Only the heresiologist, aš-Šahristānī (d. 1153), surpasses al-Ya'qūbī: in a chapter devoted to the religious beliefs of the 'Sabaeans', he expounds on the religious thought of several Greek philosophers of antiquity. But in contrast to al-Ya'qūbī, he does not draw a connection to the Roman Empire and the religious environment of early

${ }^{31}$ at-Tabarī, tārīh ar-rusul wa-l-mulūk, vol. I: 604, defines a Roman emperor as 'idolater' (șāhib watan); al-Mas 'ūdī, murū̌g ad-dahab II, 299, § 721: 35 (Arabic ed.), 271 (French transl.), claims that, in the times of Tiberius and Caligula, the people venerated statues and pictures (wa-l-qaum lā ya 'rifüna gair 'ibādat at-tamāț̄il wa-ș-șuwar) or, in II, 304, § 726: 37 (Arabic ed.), 272 (French transl.), Nero delighted in the veneration of statues and idols (ragaba fì 'ibādat at-tamāț̄ll wa-l-aṣnām); cf. IV, 57f., § 1385: 388 (Arabic ed.), 531 (French transl.); al-Bīrūnī, ațār al-bāqiya: 29; al-Bakrī, kitāb al-masālik wa-l-mamālik § 487: 307, follows al-Mas 'ūd̄̄, and introduces the term 'Magians' (ahl al-ma ğ ūsiya) in $\S$ 490: 308. Ibn al-Atīr, al-kāmil fí-t-tārīh , vol. I: 324-26, refers to the 'religion of the Sabaeans' (dīn aș-ṣābi'īn), which he defines as the veneration of the seven planets (wa kāna lahum așnām 'alā asmā' al-kawākib as-saba 'a 'alā 'âdat aṣ-șābi' '̄n). He also mentions a temple built by the Emperor Hadrian in Jerusalem and dedicated to Venus. Abū-1Fidā', tārīh așnām), which he defines as the veneration of the seven planets (wa lahum așnām 'alā așmā' al-kawākib as-saba 'a ya 'budūnahā). Furthermore, in the geographical chapter on al-Andalus that forms part of his geographical work (Abū-l-Fidā', taqwìm al-buldān: 183), Abū-l-Fidā' mentions a temple of Venus (haikal az-Zahra) that was venerated by the people of pre-Christian Spain. Also see Ibn Haldūn, tārīh, vol. II: 409-10, 417-18, 421, 424-25, 428, 433.

The Medieval History Journal, 12, 2 (2009): 431-472 
expanding Christianity. ${ }^{32}$ Considering this general lack of information about Roman paganism, it would be unrealistic to expect detailed descriptions of specific Western forms of Roman or Roman-influenced Iberian, Italic, Celtic or Germanic paganism.

While al-Ya'qūbī does refer to the apostles and Paul's missionary activity, later historiographical work contain more details. Authors such as at-Tabari and al-Mas'ūdī name apostolic activity in the East and the West. ${ }^{33}$ The most widely known place in the West is Rome, which is commonly associated with the apostles Peter and Paul. The latter appear either in historiographical writings dealing with Roman history or in geographical treatises describing the city of Rome. Most authors, ranging from at-Tabari to Ibn Haldūn, relate that Peter was martyred together with Paul after having called people to the faith in the city of emperors. ${ }^{34}$ Some even attribute the conversion of a Roman ruler or his wife to one of the two. ${ }^{35}$ Muslim historiographers rarely name other localities in the western half of the Roman Empire: at-Tabari mentions protagonists of Christian preaching in North Africa, but no parts of Western Europe. ${ }^{36}$ From the eleventh century onwards, the Iberian Peninsula seems to have been acknowledged as apostolic missionary terrain as well. Perhaps, through recourse to Christian tradition based on Paul's letter to the Romans, the ethnographer, al-Bakrī, claims that the Emperor Constantine accomplished the evangelisation of Spain allegedly initiated by Saint Paul. ${ }^{37}$ Information about the cult of Saint Jacob, the apostle said to be

${ }^{32}$ Shahrastani, Livre des religions et des sectes, vol. II: 14-51 (commentary), 175-362.

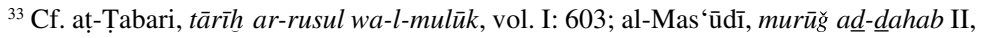
300-303, § 723-25: 36-37 (Arabic ed.), 271-72 (French transl.).

${ }^{34}$ Ibn Hurradadbih, kitāb al-masālik wa-l-mamālik: 115, only mentions that their bodies are to be found in Rome; at-Ṭabari, tārīh ar-rusul wa-l-mulūk, vol. I: 603; Ibn Rustah,

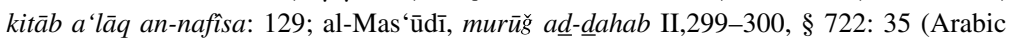
ed.), 271 (French transl.), see fn. 7 for further references; al-Bakrī, kitāb al-masālik wa-lmamālik § 487: 307; Ibn al-Ațīr, al-kāmil fì-t-tārīh, vol. I: 325; Abū-1-Fidā', tārīhn: 107; Ibn Haldūn, tārīh hol. II: 294, 297, 411.

${ }^{35}$ aț-Ṭabari, tārīh ar-rusul wa-l-mulūk, vol. I: 604, who probably refers to Constantine in this rather strange version; Ibn al-Atīr, al-kāmil fī-t-tārīh , vol. I: 325 , who copies at-Tabari and probably refers to Constantine and Helena, misplacing them chrono-logically; the same goes for Abū-1-Fidā', tārīh: 107; Ibn Haldūn, tärīh, vol. II: 294, 411, seems to copy one of the three former sources.

${ }^{36}$ at-Ṭabari, tārīh ar-rusul wa-l-mulūk, vol. I: 603.

37 al-Bakrī, kitāb al-masālik wa-l-mamālik § 495: 310, speaking of Constantine: 'And he is the one who accomplished the project (aniyan) of the disciple Paul (Yūliš) in alAndalus, Mérida, Sevilla and Carmona in this age.' (wa huwwa alla $\underline{\underline{\imath}}$ amd̄a anyan Yūliš

- The Medieval History Journal, 12, 2 (2009): 431-472 
buried in Spain, must have been transferred to the East at the latest around the thirteenth or fourteenth century, when Abū-l-Fidā', replicating the geographical text of the North African historiographer, Ibn Sa'îd alMagribī, mentions the apostle's tomb in Santiago de Compostela. ${ }^{38} \mathrm{Gaul}$, the Germanic provinces or Britain are never referred to in connection with the apostles - contrary to medieval Latin-Christian tradition, which tries to link local Christian history as closely as possible to the apostles and other characters of the New Testament. ${ }^{39}$

Given the fact that many Muslim historiographers grew up and lived in regions that had been predominantly Christian before the spread of Islam, ${ }^{40}$ it is hardly surprising that they were aware of certain Christian traditions; most notably the cult of martyrs. Hence, aside from al-Ya'qūbī, Muslim historiographers ranging from aț-Ṭabarī to Ibn Haldūn rarely failed to mention that, in the phase before the rule of Constantine, Christians in the Roman Empire had been regularly persecuted, tortured and put to death because of their faith. ${ }^{41}$ Apart from the martyrdom of

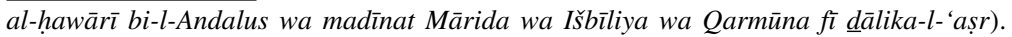
The apostle Paul had announced a missionary expedition to Spain in Romans 15: 24, 29. Cf. Harnack, Mission und Ausbreitung des Christentums: 920; Baus, 'Von der Urgemeinde zur frühchristlichen Großkirche': 124; Menéndez-Pidal, Historia de España, vol. II/2: La España romana, XCII; as well as Gams, Die Kirchengeschichte von Spanien, vol. I: 55-75, on the discussion if Paul really executed this plan.

${ }^{38}$ Abū-1-Fidā', taqwīm al-buldān: 183; cf. Ibn Sa'īd al-Magribī, al-ğuğrāfiya: 192. Santiago de Compostela is already mentioned earlier as an archbishopric by the Andalusian historiographer, Ibn Hayyān, Crónica de los emires: 306-07 (183v-84r). The Andalusian geographer, al-Bakrī, kitāb al-masālik wa-l-mamālik § 1489: 891, mentions Santiago de Compostela as an important place for Christian pilgrimage.

${ }^{39}$ Cf. Levison, 'Die Anfänge rheinischer Bistümer in der Legende': 9: 'In verschiedensten Ländern hat man im Mittelalter die Gründung von Kirchen in apostolische Zeiten zurückgeführt, so in Italien, Dalmatien und den Donauländern, in Gallien, Spanien und Britannien; teilweise bringt man sie in unmittelbare Verbindung mit Personen des Neuen Testaments wie Maria Magdalena, Martha, Lazarus, Joseph von Arimathia, man findet die Begründer wieder in der Schar der 72 Jünger, macht Martialis von Limoges zum 13. Apostel. Es sind zum Teil ganz abenteuerliche Erfindungen und Geschichtsklitterungen, nicht ohne Belang für die Kenntnis mittelalterlicher Geistesart.'

${ }^{40} \mathrm{Cf}$. at-Tabarī, tārīh ar-rusul wa-l-mulūk, vol. I: 540, 606, who, naming his sources, refers to 'scholars among the people of the book in Palestine' (qaum min 'ulamā' ahl alkitāb min ahl al-filasțīn) and 'the testimony of Christians' (fi qaul an-nașārāa).

${ }^{41}$ Ibid.: 604, is rather curt; more informative: al-Mas 'ūdī, murū̌g ad-dahab II, 304-06, § 726-28: 37-39 (Arabic ed.), 272-74 (French transl.), as well as the following paragraphs

The Medieval History Journal, 12, 2 (2009): 431-472 
Peter and Paul, whose tombs in the Church of Saint Peter generally form part of geographical descriptions of Rome, ${ }^{42}$ the persecution of Decius is most prominent, since it is associated with the flight of the legendary Seven Sleepers of Ephesos mentioned in the Qur'ān. ${ }^{43}$ Seldom are the reasons for persecuting Christians discussed: citing the interpolated and extended Arabic version of Orosius, Ibn Haldūn mentions that they were held responsible for epidemics, while stating at the same time that the persecution of Christians, in turn, caused (divinely ordained) epidemics and droughts. ${ }^{44}$ But Muslim historiographers were also aware of the fact that the persecutions did not seriously impede the diffusion of Christianity within the Roman Empire and that missionary work was possible. Many of them, beginning with at-Tabari, noted that sympathy for Christianity could occasionally even be found in imperial circles before the rise of Constantine..$^{45}$ Muslim historiographers writing from the tenth century

dealing with the pagan Roman emperors; al-Bīrūnī, atāâr al-bāqiya: 93; al-Bakrī, kitāb al-masālik wa-l-mamālik § 487: 307; Ibn al-Ațīr, al-kāmil fì-t-tārīh, vol. I: 325-28; Abū1-Fidā', tārīhn: 107, 110; Ibn Haldūn, tārīh, vol. II: 411, 415, 417, 419, 421, 423-30, 433.

${ }^{42}$ Ibn Hurradadbih, kitāb al-masālik wa-l-mamālik: 113-15; Ibn al-Faqīh al-Hamadāāī, muhtaṣar kitāb al-buldān: 149-51; Ibn Rustah, kitāb a 'lāq an-nafìsa: 128-30; al-Mas 'ūdī, murū $\breve{g}$ a $\underline{\text { d-d }}$ dahab I, 129, § 128: 74 (Arabic ed.), 55 (French transl.); II, 299-300, § 722: 35 (Arabic ed.), 271 (French transl.); al-Bakrī, kitāb al-masālik wa-l-mamālik, § 804: 478.

${ }^{43}$ al-Ya'qūbī, tārīh al-Ya'qūbī, vol. I: 133, wrongly believes that the Seven Sleepers reappeared under Decius, whose rule he places after the rule of the apostate Julian; at-

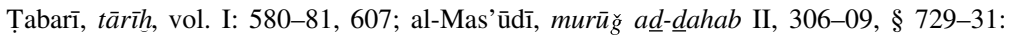
39-40 (Arabic ed.), 273-74 (French transl.); II, 164-5, § 590: 290 (Arabic ed.), 221 (French transl.); al-Bīrūn̄̄, ațār al-bāqiya: 94; al-Bakrī, kitāb al-masālik wa-l-mamālik § 494: 310; Ibn al-Ațīr, al-kāmil fì-t-tārīh, vol. I: 328; Rašīd ad-Dīn, Frankengeschichte: 62-63; Abū-1-Fidā', tārī̄ : 110; Ibn Haldūn, tārīh , vol. II: 424. For the story of the Seven Sleepers in the Qur'ān, see sura 18: 9-26; for its Latin equivalent, cf. Heinzelmann, 'La réécriture hagiographique': 59-68, with further literature.

${ }^{44}$ Ibn Haldūn, tarīh, vol. II: 419, 424-25.

${ }^{45}$ at-Tabarī, tārīh ar-rusul wa-l-mulük, vol. I: 604 , who probably refers to Constantine in this rather strange version; al-Mas 'ūdī, murūg ad- $\underline{d}$ dahab II,304, § 726: 37 (Arabic ed.), 272 (French transl.), states that Christianity was diffused successfully among the Romans within a paragraph that mentions the persecutions under Nero; al-Bakrī, kitāb al-masālik wa-l-mamālik $\S 492: 309$, who explains the epithet 'pius' of the Emperor Antonius with the emperor's moral lifestyle and his benevolence towards the Muslims (sic!). In § 493: 310, al-Bakrī claims that the mother of Emperor Alexander Mammaea was Christian, as well as the Emperor Philippus Arabs, whom he defines as the first Roman emperor to have converted to Christianity; Ibn al-Atīi, al-kāmil fì-t-tārīh $\underline{h}$, vol. I: 325 , who copies ațTabarī and probably refers to Constantine and Helena, misplacing them chronologically;

- The Medieval History Journal, 12, 2 (2009): 431-472 
onwards also believed that the Emperor Philippus Arabs had converted to Christianity and was killed by his successor Decius because of his Christian affinity. ${ }^{46}$

Only the Persian historiographer, Rašīd ad-Dīn (d. 1318), and Ibn Haldūn mention the last persecution under Diocletian. ${ }^{47}$ All Muslim historiographers, however, were aware that things changed with Constantine, probably the best-documented Roman ruler in Muslim historiography whose conversion is often described in detail. Accounts of a vision before an important battle which recall the respective passages in the works of Lactantius and Eusebius, are not only related by al-Ya'qūbī but also by al-Mas 'ūdī, al-Bakrī, Ibn al-Atīir, Rašīd ad-Dīn, Abū-l-Fidā' and Ibn Haldūn. They compete with accounts of Constantine's miraculous cure at the hands of Pope Silvester reproduced by al-Bakrī, Ibn al-Atīr, Rašīd ad-Dīn and Ibn Haldūn. Rašīd ad-Dīn mentions another legendConstantine converted because Pope Silvester managed to resuscitate a cow (sic!)—as well as the so-called 'Donation of Constantine'. Furthermore, Constantine's motives, detailed descriptions of the council of Nicaea and its decisions, reports about Constantine's institution of churches as well as measures against pagan cults and the Jews of Jerusalem form part of his rule as related by most Muslim historiographers with the exception of at-Tabarīi. ${ }^{48}$

The consequences of Constantine's conversion too are assessed: it is with Constantine that the Roman world turned Christian. According to at -Ṭabarī, Christianity thus took root among the Romans. ${ }^{49}$ Al-Mas 'ūdī

the same goes for Abū-l-Fidā', tārīh: 107; Ibn Haldūn, tārīhh, vol. II: 294, 409, 411, seems to copy either at-T Tabarī or one of his copyists. On page 416 , he attributes a moral lifestyle and tolerance towards Christians to the Emperor Carus. On page 422, he mentions a Christian affiliation of the Emperor Alexander Mammaea.

${ }^{46}$ al-Mas'ūdī, 133; al-Bakrī, kitāb al-masālik wa-l-mamālik § 493: 310; Ibn al-Ațīr, al-kāmil fì-t-tārīh, kitāb at-tanbīh wa-l-išrāf, vol. I: 327-28; Abū-1-Fidā', tārrīh, p. 110; Ibn Haldūn, tārīh, vol. II: 423-24.

${ }^{47}$ Rašīd ad-Dīn, Frankengeschichte: 64, and Ibn Haldūn, tārīh, vol. II: 427-31, 433.

${ }^{48}$ al-Ya 'qūbī, tārīh al-Ya 'qūbì, vol. I: 132-33; aṭ-Ṭabarī, tārīh, vol. I: 581, 604-605, 608; al-Mas' 'ūdī, murū̌̆ a $\underline{\text { d-d }}$ dahab II, 311-18, § 734-38 and § 741: 41-46 (Arabic ed.), 275-78 (French transl.); al-Bakrī, kitāb al-masālik wa-l-mamālik, § 495-99: 310-11; § 797: 474; § 1488: 891; Ibn al-Ațīr, al-kāmil fì-t-tārīh, vol. I: 329-31, 396-97; Abū-1Fidā', tārīh: 64, 84, 110, 168; Rašīd ad-Dīn, Frankengeschichte: 64-65, especially 65 (fn. 335); Ibn Haldūn, tārīh, vol. II: 427-31, 433-37.

${ }^{49}$ at-Tabarī, tārīh , vol. I: 604, mentions the conversion of an unnamed ruler who took and venerated the cross on which Jesus was crucified and later killed Jews. According to 
defines Constantine as the 'herald of Christianity' ${ }^{50}$ but is well aware of the fact that it took the additional efforts of Constantine's son, Jovian, Gratian and Theodosius I to ensure the triumph of Christianity. ${ }^{51}$ This is echoed by al-Bakri ${ }^{-52}$ and Ibn al-Atîr. According to the latter, Constantine fought for Christianity until the people accepted it, with the effect that they remained Christian up to the author's present time. ${ }^{53}$ According to less refined interpretations such as the one provided by Șā' 'id al-Andalusī, Constantine called on his subjects to embrace Christianity: all of them obeyed.$^{54}$ Thus, Muslim historiographers were aware of the fact that this phase of Roman history was characterised by a shift of religious allegiance among the empire's ruling elite. The apostasy of the Emperor Julian, mentioned by most historiographers except for al-Ya 'qūbī, is understood as a short interlude that did not seriously impede the progress of establishing Christianity. ${ }^{55}$ This is valid as well for the ruling period of later Arian emperors such as Valens, who is mentioned occasionally. ${ }^{56}$ The

at-Tabarī, the Romans acquired the fundamentals of Christianity at this moment ( $\mathrm{fa}$ min hunālika kāna aṣl an-nașrāniyya fí-r-Rüm). One can assume that he was speaking of Constantine, since, on page 581, he defines Constantine as the ruler who converted to Christianity and whose mother Helena set out to search for and find the cross. It is not clear why at-Tabarī did not choose to combine both narratives.

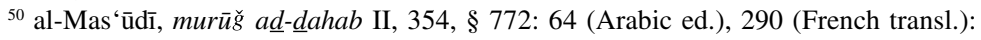
(al-mužhir li dīn an-nașrāniya).

${ }^{51}$ Cf. ibid. II, 323-28, § 744-48: 47-49 (Arabic ed.), 278-80 (French transl.). This is how al-Mas 'ūdī explains the causes for the triumph of Christianity, which he announces to clarify in II, 313, § 736: 42 (Arabic ed.), 276 (French transl.).

${ }^{52}$ al-Bakrī, kitāb al-masālik wa-l-mamālik, § 495-502: 310-12.

${ }^{53} \mathrm{Ibn}$ al-Ațīr, al-kāmil fì-t-tārīh, vol. I: 329 (wa huwwa allad̄i tanașșara min mulūk ar-Rūm wa qātila 'alaihā hattā qabalahā an-nās wa dānū bihā ilā hā Haldūn, tārīhn, vol. I: 413 (ilā an ğā'a Qusțtanțīn wa aḥada bihā wa istamarrū 'alaihā); vol. II: 432.

${ }^{54}$ Șā‘id al-Andalusī, kitāb țabaqāt al-ummam: 99-100; cf. Abū-1-Fidā', tārīhn: 168.

${ }^{55}$ al-Ya 'qūbī, tārīh al-Ya 'qūbī, vol. I: 133; aṭ-Ṭabarī, tārīh, vol. I: 608; al-Mas 'ūdī,

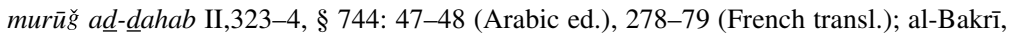
kitāb al-masālik wa-l-mamālik § 500: 312; Ibn al-Ațīr, al-kāmil fì-t-tārīh, vol. I: 331; Rašīd ad-Dīn, Frankengeschichte: 66; Abū-1-Fidā', tārīh: 84, 110; Ibn Haldūn, tārīh, vol. II: 437.

${ }^{56}$ al-Mas 'ūdī, Rašīd ad-Dīn and Ibn Haldūn echo orthodox Christian polemic against a heretic ruler, who 'renounced' Christianity and thus damaged the Christian faith, defined by the former two as Valentinian, by the latter as Valens; cf. al-Mas ' $\overline{\mathrm{u} d \overline{1}}$, murū $\breve{g}$ a $\underline{d}$ - $\underline{d} a h a b$ II, 325-6, § 746-7: 48-49 (Arabic ed.), 279-80 (French trans1.); Rašīd ad-Dīn, Frankengeschichte: 66; Ibn Haldūn, tārīh, vol. II: 438-40, 489-93.

- The Medieval History Journal, 12, 2 (2009): 431-472 
Christianisation of the Roman world after Constantine was accompanied, as most Muslim historiographers were well aware of, by internal discussions concerning the correct definition of Christianity as well as the condemnation of several Christian figures such as Arius, Macedonius and Nestorius at the councils of Nicaea, Constantinople, Ephesos, Chalcedon, etc. ${ }^{57}$

Contrary to what Lewis implies, the Christianisation of the Roman Empire was seldom regarded by Arab writers as a negative development. If al-Mas 'ūdī criticised the Romans for converting to Christianity, it was not because he believed them to have adopted the wrong religion in a period before the advent of Islam; al-Mas ' $\overline{\mathrm{u}} \mathrm{d} \overline{\mathrm{i}}$ does not polemicise against the conversion as such but against the ensuing neglect of pre-Christian scientific achievements: $:^{58}$

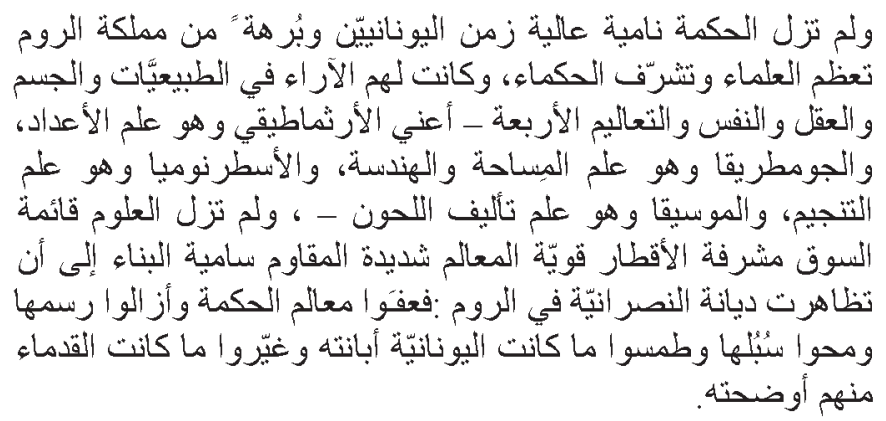

Science did not stop growing on a high level in the times of the old Greeks $[a l-Y \bar{u} n \overline{a n n i y \bar{n}}]$ and the early Romans/Byzantines [ar-Rüm]. The learned received praise and the wise honours. They had formed opinions about natural phenomena, the body, the intellect, the soul and the four liberal arts: I am speaking of arithmetics - the science of numbers, of geometry - the science of measurement and construction, of astronomy-the science of the stars,

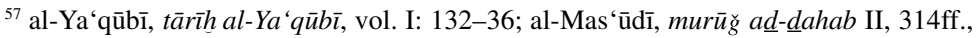
§ 737: 42 (Arabic ed.), 276 (French transl.); al-Bakrī, kitāb al-masālik wa-l-mamālik, § 499: 312; Ibn al-Ațīr, al-kāmil fì-t-tārīh, vol. I: 330-33; Ibn Haldūn, tārīh hol. II: 300-05, 434, 438, 441 and vol. I: 411-16 (cf. Ibn Khaldūn, al-Muqaddimah VI, 18: 478-50); Abū1-Fidā', tārīh: 110-14, 164-66.

${ }^{58}$ al-Mas 'ūdī, murūğ ad- $\underline{d} a h a b$ II, 320f., § 741: 45-46 (Arabic ed.), 278 (French transl.); translated by the author. 
and of music - the science of composing melodies. These sciences continued being valued and honoured everywhere and rested on stable fundaments until the Christian religion appeared among the Romans/Byzantines: This was a hard stroke for the scientific system. Its traces were lost and its channels wiped out. Everything the old Greeks had brought to light disappeared and the discoveries that were made thanks to the ancient genius were altered.

Thus, Muslim historiographers had a relatively clear picture of the chronological phases and issues related to Christian conversion in the Roman Empire. It cannot be taken for granted, however, that Muslim historiographers automatically equated the Christianisation of the Roman Empire with the conversion of Western, later Latin-Christian Europe. Often, explicitly drawing upon on Eastern Christian sources, ${ }^{59}$ Muslim historiographers writing on Roman and Byzantine history concentrated on the Middle East, especially if they were of eastern origin. As has already been addressed in the paragraph dealing with the missionary activity of Jesus' disciples, references to places in Western Europe are very scarce in Muslim narratives dealing with Roman history. Thus, the question has to be posed as to whether Muslim authors attributing the conversion of the empire to Constantine and his successors, believed that this process entailed the Christianisation of Western Europe. To answer this question, it is necessary to analyse if Western Europe was acknowledged as a part of the late antique Roman Empire.

In a paragraph devoted to the description of the Roman-Byzantine empire's extension before the spread of Islam, al-Ya 'qūbī (ninth century) remarks vaguely that it extended to the lands of the Franks and the Slavs. Yet, in addition to the fact that he never mentions any Western activity in his list of Roman emperors, the ensuing list of place-names includes no localities in the West apart from Rome and Sicily. ${ }^{60}$ The ninth-century geographer, Ibn Hurradadbih, states very generally that 'the people of the West' had been under Roman rule which had originated in the West, but only mentions Rome, Sicily and cities of Northern Africa in

59 at-Ṭabarī, tārīh, vol. I: 540 (qaum min 'ulamā' ahl al-kitāb min ahl al-filasțīn), 606 (fī qaul an-nașāra); al-Mas 'ūdī, murū̌̆ ad-dahab II, 297-8, § 719: 34 (Arabic ed.), 270-71 (French transl.); II, 304-05, § 726: 38 (Arabic ed.), 272-73 (French transl.); II, 309-10, § 733: 40 (Arabic ed.), 274 (French transl.); al-Bīrūn̄̄, ațār: 97 (naqalahā min kitābin li-malik ar-Rūm)

${ }^{60}$ al-Ya'qūbī, tārīh al-Ya'qūbì, vol. I: 137.

- The Medieval History Journal, 12, 2 (2009): 431-472 
connection with Rome/Byzantium. ${ }^{61}$ Ibn Rustah (d. after 913) defines the 'city of Britannia' as the ultimate outpost of the Roman-Byzantine Empire ${ }^{62}$ at-Tabarī (d. 923) states explicitly that he will only list the Roman emperors who ruled Greater Syria. ${ }^{63}$ Evidently copying al-Iștahrī (d. 951), Ibn Hauqal (tenth century) claims that Franks, Galicians and Byzantine Romans had the same religion and formed part of the same political entity, even though they spoke different languages. ${ }^{64}$ Thus, several references point to the fact that Muslim authors of the ninth and tenth centuries had knowledge of a political, cultural, religious and thus, historical relationship between the Roman-Byzantine Empire and the western regions. However, they do not seem to have been able to define the exact character and historical development of this relationship.

More explicit statements can be found from the tenth century onwards. Al-Mas 'ūdī (d. 956) mentions pagan Roman temples situated in the 'lands of the Franks' as well as tetrarchian rule in the West. ${ }^{65}$ The Andalusian historiographer, Șā'id al-Andalusī (d. 1070), explicitly acknowledges that the Roman Empire had encompassed Spain and Gaul. ${ }^{66}$ Ibn Hayyān (d. 1076) and al-Bakrī (d. 1094), both from the Iberian Peninsula, mention Roman rule in Spain. ${ }^{67}$ The Eastern historiographer, Ibn al-Atīr (d. 1233), places the dominions of certain tetrarchian rulers in the West ${ }^{68}$ and states that the Goths wrested the Iberian Peninsula from Roman rule. ${ }^{69}$ Ibn Haldūn (d. 1406) provides the greatest number of links between Western Europe and the Roman Empire by describing the Roman conquest of the Iberian Peninsula, military campaigns in the lands of the Franks (Ifranğa) and Britain (Barìtaniya) at the end of the

${ }^{61}$ Ibn Hurradadbih, kitāb al-masālik wa-l-mamālik: 83, 91-92, 104.

${ }^{62}$ Ibn Rustah, kitāb a 'lāq an-nafìsa: 130.

${ }^{63} \mathrm{Cf}$. aț-Ṭabarī, tārīh , vol. I: 606-08.

${ }^{64}$ al-Iștaḩ rī, kitāb al-masālik wa-l-mamālik: 9; Ibn Ḥauqal, kitāb șūrat al-ard: 14.

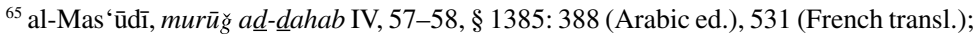
kitāb at-tanbīh wa-l-išrā $f: 136,145$.

${ }^{66}$ Ṣā'id al-Andalusī, kitāb țabaqāt al-ummam: 97.

${ }^{67}$ Ibn Ḥayyān al-Qurțub̄i, al-muqtabis min abnā' ahl al-Andalus, vol. V: 272-73; alBakrī, kitāb al-masālik wa-l-mamālik § 479-80: 303; § 483: 305-306; § 1494-5: 893-94; $\S 1513$ : 902-03.

${ }^{68}$ Ibn al-Atīir, al-kāmil fì-t-tārīh, vol. I: 329.

${ }^{69}$ Ibid., AH 92, vol. IV: 557-58. 
Roman republic and during the principate, tetrarchian rule in the Roman West as well as the substitution of Roman by Visigothic rule in Spain. ${ }^{70}$ He also asserts that the Franks seceded and founded an independent polity when the empire disintegrated. ${ }^{71}$ It should be noted that most of these authors were either of Andalusian origin or had access to translations or Arabic synopses of Latin texts containing information about Roman rule in Western Europe. ${ }^{72}$

To conclude, it is difficult to ascertain if all Muslim historiographers and geographers clearly grasped the fact that Christianity had reached Western Europe via the Roman Empire. That it had been carried to Rome by the apostles was common knowledge, widely diffused already among earlier historiographers. But, how it spread from there, which other regions had been affected by it under Roman rule, seems to have been less clear. Only from the tenth century onwards, certain historiographers seem to have had a clear notion of the extension of Roman rule to the West. But only rarely does one find statements such as the one by Șā'id al-Andalusī, who, evidently oversimplifying, acknowledged the Roman contribution to the spread of Christianity—at least to a certain extent. ${ }^{73}$

${ }^{70}$ Ibn Haldūn, tārīh , vol. II: 386, 400, 405, 406, 427-31, 433, 490-93; vol. IV: 252. Issawi, 'Ibn Khaldun on Ancient History. A Study in Sources': 54, is wrong, when he states: 'Ibn Khaldun does not seem to have known that Rome dominated the Western Mediterranean and, for many centuries, ruled the two regions with which he was most familiar, Spain and North Africa...'

${ }^{71}$ Ibn Haldūn, tārīh, vol. V: 385 (fa lamma inqaradat daulat ūlā'ika istaqalla ha'ulā'’ al-Ifranğ bi-mulkihim wa iftaraqū mițla daulat al-Qūṭ bi-l-Andalus).

${ }^{72}$ It is not clear which sources were used by Șā 'id al-Andalusī. Ibn Hayyān, al-muqtabis, vol. V: 274-76, whose knowledge about Romans and Visigoths clearly implies that he had access to Latin-Christian traditions, cites 'Isā bin Aḥmad ar-Rāzī, probably the son of Ahmad bin Muhammad ar-Rāzī, who may have had access to an Arabic adaptation of Orosius' Historia adversus paganos; cf. Crónica del moro Rāsis: LI. al-Bakrī, kitāb almasālik wa-l-mamālik: 18-23; § 812: 482, mentions Orosius several times. The account of Visigothic history provided by Ibn al-Atīi, al-kāmil fì-t-tārīh , vol. IV: 558-61, is clearly dependent on Latin-Christian traditions, even if the author does not cite them. Rašîd adDīn, Frankengeschichte: 13-15, 41, 46, drew back on a translation of the Latin chronicle written by Martinus Oppaviensis. Ibn Haldūn, tārīh, vol. II: 402, 414-15, cites Orosius extensively; cf. Issawi, 'Ibn Khaldun on Ancient History': 62-66; Badawī, Awrūsiyūs. tārīh al-'ālam: 20-47; Levi della Vida 'La Traduzione araba delle storie di Orosio': 257-93; Christys, Christians in al-Andalus (711-1000): 135-57.

${ }^{73}$ Șā ‘id al-Andalusī, kitāb țabaqāt al-ummam: 99-100. Translation adapted from: Șā'id al-Andalusī, Science in the Medieval World: 'Book of the Categories of Nations': 32.

- The Medieval History Journal, 12, 2 (2009): 431-472 


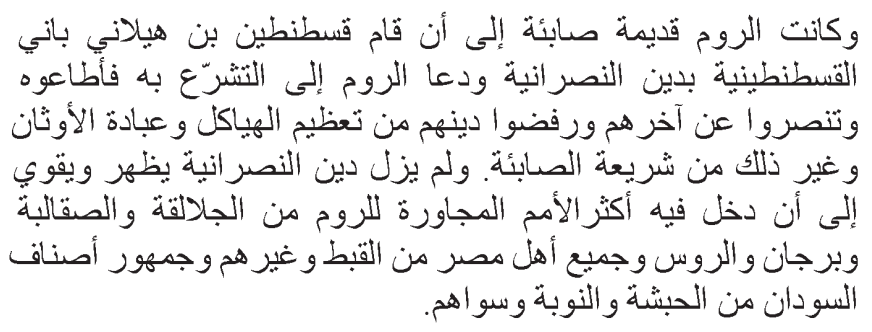

The Romans of the past were Sabians until Constantine, son of Helena, the founder of Constantinople, converted to Christianity and called on his subjects to embrace it. They all obeyed him, became Christians, and rejected the worship of idols, the glorification of temples, and other rites of the Sabian doctrine. Christianity kept growing and getting stronger until it was adopted by most of the nations neighbouring the Roman, such as the Galicians, the Slavs, the Burğān, the Rūs, and all the people of Egypt, such as the Copts and others, and the majority of the sects of the Sudan, such as the Ethiopians, Nubians, and others.

Ibn Haldūn is one of the few other authors to draw a connection between the Roman Empire and the diffusion of Christianity among the postRoman peoples of Latin Europe by mentioning that Goths and Franks converted under Roman influence. ${ }^{74}$

\section{Christianisation beyond the Roman Empire}

It is conspicuous that the transformation of the Roman Empire as well as the turmoil of the period of migrations-factors extremely important for the spread of Christianity beyond the geographical and chronological confines of the Roman Empire-are reflected only to a limited degree in Arab-Islamic historiography. An analysis of the lists of Roman emperors so assiduously compiled and copied by Muslim authors of universal history over the centuries shows that-among the authors analysed within the scope of this article-only Abū-1-Fidā' and Ibn Haldūn mention the division of the Roman Empire into an eastern and a western half under the sons of Theodosius I in 395, while other contemporary writers

\footnotetext{
${ }^{74}$ Ibn Haldūn, tārīh, vol. IV: 252.
} 
continue their list of Roman-or rather Byzantine-emperors, which they lead up to Heraclius or further, thereby implying that things went on as before. Neither the deposition of the last Western Roman emperor in 476, not even the restauratio imperii at the hands of Justinian I is mentioned: Roman history is viewed and retold from a Byzantine point of view. Continuity plays a much larger role than from a western perspective. ${ }^{75}$

This should not, however, be taken to mean that the state of turmoil in the western half of the empire, extending from the end of the fourth to the sixth century, went completely unnoticed, at least from the eleventh century onwards. Drawing on Latin traditions, al-Bakrī, Ibn al-Atīr and Ibn Haldūn provide a more or less adequate description of the migration and ensuing sack of Rome at the hands of the Visigoths in 410 as well as the Visigoths' subsequent settlement in Gaul and Spain. ${ }^{76}$ Ibn Haldūnseemingly the only historiographer to do so-also attributes the creation of an independent polity at the expense of the Roman Empire to the Franks, ${ }^{77}$ and even writes about the chaotic situation on the Iberian Peninsula during the period of migration, mentioning peoples that may be identified as Vandals, Sueves and Alans. ${ }^{78}$ Other authors, however, seem to have believed that the emergence and formation of 'barbarian' successor states took place at a later date, interpreting this development as a secession of Western peoples from Constantinople. Șā'id al-Andalusī, and later Ibn al-Atīr, claim that this happened in 952, thereby probably echoing the Byzantine perspective of political relations with the Latin-Christian West. ${ }^{79}$ Considering the fragmentary knowledge Muslim historiographers had of the Western Roman Empire during the migration

${ }^{75}$ al-Ya'qūbī, tārīh al-Ya'qūbì, vol. I: 133-36; aț-Ṭabarī, tārīh , vol. I: 608; al-Mas'ūdī, murū $\breve{g}$ ad-dahab II, 325, § 746-7: 48-49 (Arabic ed.), 279 (French transl.); alBakrī, kitāb al-masālik wa-l-mamālik § 502-07: 313-15; Ibn al-Āīi, al-kāmil fì-t-tārīh , vol. I: 323, 331-32; Abū-1-Fidā', tārīh : 110; Rašīd ad-Dīn, Frankengeschichte: 66-68; Ibn Haldūn, tārīh , vol. II: 440-44, 489-93.

${ }^{76}$ al-Bakrī, kitāb al-masālik wa-l-mamālik, § 503-16: 312-19; Ibn al-Aț̄ī, al-kāmil fīt-tārīh, vol. IV: 558-61; Ibn Haldūn, tārīh, vol. II: 490-92.

${ }^{77}$ Ibid., vol. V: 385 (fa lamma inqaradat daulat ūlā'ika istaqalla ha'ulā'ō al-Ifranğ bimulkihim wa iftaraqū mițla daulati-l-Qūt bi-l-Andalus).

${ }^{78}$ Ibid., vol. II: 490. Cf. al-Bakrī, kitāab al-masālik wa-l-mamālik, § 1487: 890, who also asserts that al-Andalus was named after the Vandal people who had settled there. Unfortunately and contrary to his claim, he does not provide further information on the Vandals.

${ }^{79}$ Șà 'id al-Andalusī, kitāb țabaqāt al-ummam: 97-99 and Science in the Medieval World: 'Book of the Categories of Nations': 31-32. Ibn al-Atīr speaks about the same event but

- The Medieval History Journal, 12, 2 (2009): 431-472 
period, it is not surprising that they were not able to draw a broad picture of the post-Roman process of Christianisation.

Among the peoples in pre-Islamic Western Europe, who definitely caught the attention of the Arab-Islamic world, were the Visigoths of Spain. However, it took several centuries for Muslim historiographers to acquire enough information with the help of translated Latin-Christian sources so as to be able to convey essential aspects of Gothic history as well as the story of their Christianisation. Although the Visigoths were the first Western European people whose territory was appropriated by Muslim forces following the invasion of the Iberian Peninsula around 711, Muslim historiographers, until the tenth century, evidently only had access to accounts of Visigothic history that reflected the conquerors' perspective at the beginning of the eighth century and contained much legendary material..$^{80}$ Only from the tenth century onwards, Arab-Islamic historiographers seem to have had access to Latin traditions and thus, to material that provided information about Gothic Christianity that went beyond mere references to its existence. ${ }^{81}$ Probably the earliest narrative of Gothic Christianisation is provided by al-Bakrī (d. 1094) in a chapter devoted to Roman-Byzantine rulers that forms part of his ethnographical treatise. Having just described the conversion of Constantine, the appearance of Arianism, the apostasy of the Emperor Julian as well as the latter's death in a battle against the Persians, al-Bakrī continues: ${ }^{82}$

uses a different ethnic terminology, exchanging 'Latins' for 'Franks'; cf. Ibn al-Atīir, alkāmil fì-t-tārīh , vol. I: 338-39.

${ }^{80} \mathrm{Cf}$. the information on Visigothic history provided in works written in the ninth and tenth century: Ibn Ḥabīb (d. 852), kitāb at-tārīh: 136-56; Ibn 'Abdu-1-Ḥakam (d. 871), futūh miṣr wa ahbārihāa: 205-13; Ibn Hurradadbih (ninth century), kitāb al-masālik wa-lmamālik: 156-57; al-Balādurī (d. 892), kitāb futūḥal-buldān, § 269-70: 231; aț-Ṭabarī (d. 923), tārīh ar-rusul wa-l-mulūk, vol. VI: 468; Ibn al-Faqīh al-Hamadān̄i (tenth century), muhtașar kitāb al-buldān: 82-83; Ibn Rustah (d. after 913), kitāb a'lāq an-nafìsa: 79-80. An analysis is forthcoming.

${ }^{81}$ A clear influence of Latin sources can be noticed in the paragraphs written on Visigothic history by Ibn Ḥayyān (d. 1076), al-muqtabis, vol. V: 274-76; al-Bakrī (d. 1094), kitāb al-masālik wa-l-mamālik, § 501-04: 312-14; Ibn al-Atīir (d. 1233), alkāmil fì-t-tārīh, vol. IV: 558-61; Ibn Haldūn (d. 1406), tārīh, vol. II: 489-93.

${ }^{82}$ al-Bakrī, kitāb al-masālik wa-l-mamālik $\S 501$ : 312-13, trans. by the author. 


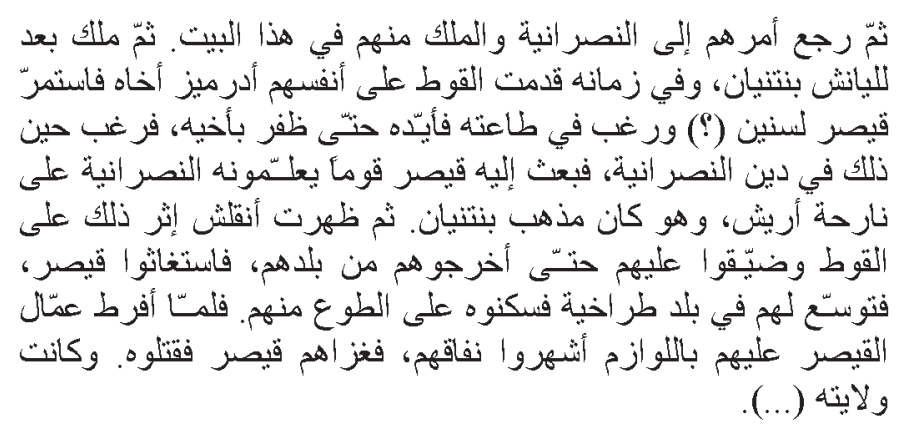

Then their [the Romans'] affairs returned back to Christianity and rule remained within this dynasty. After Julian [Lilyānuš] Valentinian [Bantinyān] ruled. In his time the Goths [al-Qūṭ] appointed his brother Adarmīz. [Athanarich? Valens?] as their guardian. He [?] remained emperor for years and wished to have him [?] under his [?] control. So he supported him [?] until he [?] was victorious over his brother. In this context he [?] wished to become Christian, so the emperor sent a group of people to him who taught him Christianity according to Arius [Aryuš] which was also the confession Valentinian [Bantinyān] belonged to. Then the Huns [Anqališ] appeared which affected and put pressure on the Goths until they evicted them from their lands. They appealed for help to the emperor who put the lands of Thrace at their disposal where they settled in obedience to them [the Romans?]. But when the functionaries of the emperor began to overburden them with duties they began to make their complaints heard. So the emperor attacked them, but they killed him. And his rule lasted...[text breaks off]

Probably drawing upon the Arabic version of Orosius, al-Bakrī offers a compressed and distorted version of the information provided by Greek and Roman historiographers of late Antiquity. ${ }^{83}$ According to al-Bakrī, the conversion of the Goths took place in a situation of political tensions: internal chaos as well as the expansion of the Huns made the Goths appeal to the emperor for help. Imperial assistance in internal struggles of the Goths had the effect of acquainting them with Christianity which they were prepared to embrace. Receiving teachers from an emperor adhering to the sect of Arius, they too became Arians. Following this, al-Bakrī

${ }^{83}$ Cf. König, Bekehrungsmotive: 49-51. al-Bakrī seems to have made use of the Arabic translation of Orosius, which he cites frequently elsewhere; cf. the Arabic translation of Orosius: Badawī, Awrūsiyūs: 464-66; kitāb Hurūšìūšs: 73-74, 374-77.

- The Medieval History Journal, 12, 2 (2009): 431-472 
informs us about the Emperor Theodosius, his miraculous defeat of Roman usurpers, his arrangement with the Goths, his death in Constantinople and his successors, as well as the Visigoths' sack of Rome, their settlement in Gaul and Spain as well as internal strife among them in Spain. A final sentence is devoted to the conversion of the Goths to Catholicism: ${ }^{84}$

$$
\begin{aligned}
& \text { ثم ملأك القوط بعده ركديد وكانت داره طليطلة. وركديد هو الذبي رجع } \\
& \text { عن خارجية القوط إلى جماعة النصر انية. }
\end{aligned}
$$

Then Reccared [Rakadīd] ruled the Goths after him, residing in Toledo. Reccared is the one who, abandoning the heresy [härišiya] of the Goths, returned to the community of Christians.

The second narrative is provided by Ibn al-Atīir (d. 1233). His account of the conversion of the Goths to Christianity forms part of his chapter on the year AH 92 which gives an introduction to the history of al-Andalus leading up to the Muslim conquest in 711. Ibn al-Atîr introduces the Goths as successors to the Romans in al-Andalus. He states that they first appeared as raiders during the rule of Emperor Claudius Gothicus who defeated them and then reappeared in the reign of Constantine. Although several authentic elements can be recognised, his account is confused and full of errors: ${ }^{85}$

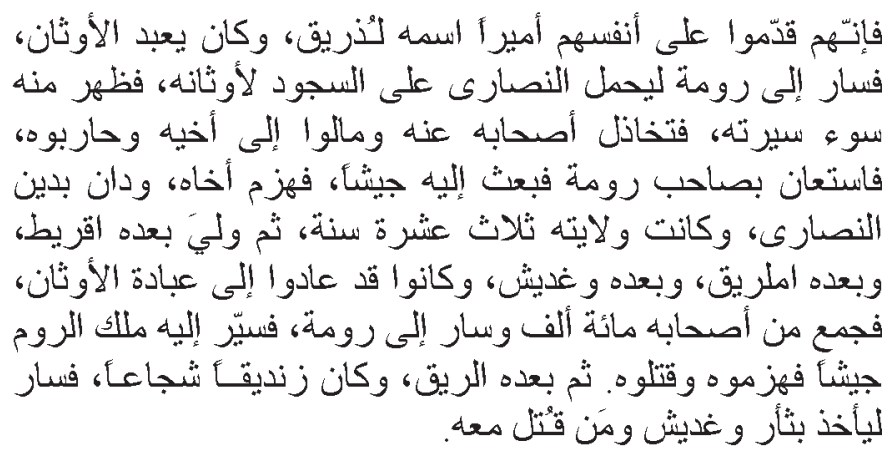

${ }^{84}$ al-Bakrī, kitāb al-masālik wa-l-mamālik, § 504: 314, trans. by the author.

${ }^{85}$ Ibn al-Atīr, al-kāmil fì-t-tārīh , AH 92, vol. IV: 558-59. 
They appointed a commander to lead them named Ludrīq who venerated idols. He set out for Rome to force the Christians to bow before his idols. In this way the latter's bad moral conduct became apparent so that his companions abandoned him, sided with his brother and waged war against him. He [the brother] turned to the ruler of Rome for help who sent him an army with which he defeated his brother. He then turned to the religion of the Christians. He ruled 13 years and was followed by Aqrīt, Amalrīq, Wagadī̌̌ [Radagaisus?] who all returned to the veneration of idols. He [Wagadīs $]$ then assembled 100.000 of his companions and set out for Rome. The ruler of Rome sent forth an army to meet him, thus defeating and killing him [Wagadī̌s]. He was followed by Alarīq, a courageous heretic [or: atheist, sceptic] who set out to revenge Wagadī̌s and those who had been killed with him.

The next time Ibn al-Ațîr mentions Christianity in a Gothic context, he describes the Visigothic conversion to Catholicism in more or less the same vein as al-Bakrī. ${ }^{86}$

Finally, Ibn Haldūn (d. 1406) provides the least information, although he treats Gothic history much more extensively than al-Bakrī. ${ }^{87}$ Citing the Arabic translation of Orosius, he states that the Goths divided into two groups during the realm of Valentinian, one adhering to the faith of Arius, the other to the faith of Nicaea. ${ }^{88}$ Further on, he treats the Visigothic adoption of Catholicism in a slightly more detailed fashion than his predecessors. ${ }^{89}$ Thus, three authors writing in and after the eleventh century mentioned and described the conversion of the Goths, first to Arian Christianity, then to Roman Catholicism. All three texts, clearly dependent on Latin traditions, unambiguously link Roman and Gothic history. The exact political circumstances surrounding the conversion to Arianism do not seem to have been completely understood. The chaotic and often obscure narratives are only intelligible if read while bearing in mind the reports of older Greek and Latin sources. ${ }^{90}$ The Arabic versions not only reflect the abundance of positions to be found in these sources but also the distortions created by cross-cultural transmission over the centuries.

Other peoples of the Iberian Peninsula are not treated in the same detail. Their Christianity is mostly acknowledged but the process of Christianisation

${ }^{86}$ Ibid.: 560.

${ }^{87}$ Ibn Haldūn, tārīh, vol. II: 18, 423-27, 438-44, 489-93.

${ }^{88}$ Ibid.: 438.

${ }^{89}$ Ibid.: 492-93.

${ }^{90} \mathrm{Cf}$. König, Bekehrungsmotive: 49-51, 53-59, on the sources and secondary literature dealing with the Christianisation of the Goths.

- The Medieval History Journal, 12, 2 (2009): 431-472 
not described: Muslim authors were, for example, clearly aware that the peoples of the North, known as 'Galicians' (Galäliqa), adhered to the Christian faith. The important Christian centre, Santiago de Compostela, was known to Muslim historiographers in the East and the West. ${ }^{91}$ alMas ' $\bar{u}$ dī and al-Bakrī even associate the Galicians with the Melchite rite and categorise them along with the Franks and the Byzantians. ${ }^{92}$ But, aside from Șā'id al-Andalusī, who attributes their conversion to Roman influence, ${ }^{93}$ no explanation exists in Arab-Islamic sources which would describe how they became Christian. Even less information about the process of Christianisation is available for the Basks as well as other smaller peoples living between al-Andalus and the Frankish kingdom who are designated as Christians in some cases ${ }^{94}$ and as unbelievers in others. ${ }^{95}$ Occasionally, their religious adherence is ignored altogether. ${ }^{96}$

Turning to Gaul, the case of the Franks is equally complicated, not in the least because of terminological difficulties. From an Arab-Islamic perspective, the Franks appear in the context of the Muslim invasion of the Iberian Peninsula as the Northeastern enemy and diplomatic partner to the Muslim polity of Spain from the eighth century onwards. Sources dealing with this period and region occasionally provide descriptions. ${ }^{97}$ During the crusades, however, the denomination 'Frank' was extended to other Latin Christians as well, thus designating different peoples of

${ }^{91}$ Ibn Hayyān, Crónica de los emires: 306-307 (183v-184r); al-Bakrī, kitāb al-masālik wa-l-mamālik, § 1489: 891; Ibn Sa‘īd, kitāb al-ğugrāafiya: 192; Abū-l-Fidā', taqwīm albuldān: 183.

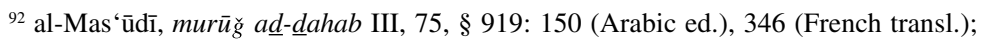
al-Bakrī, kitāb al-masālik wa-l-mamālik, § 568: 341.

${ }^{93}$ Șā'id al-Andalusī, kitāo țabaqāt al-ummam: 99-100.

${ }^{94}$ al-Iștahrī, kitāb al-masālik wa-1-mamālik: 41; Hudūd al-'ālam § 42, 21: 156; Ibn Hauqal, kitāb șūrat al-ard: 109.

${ }^{95}$ Ibn Hayyān, al-muqtabis: 311-13. It is possible, however, that the author used the epithet 'unbeliever' to describe Christians.

${ }^{96}$ Cf. al-Bakrī, kitāb al-masālik wa-l-mamālik, § 530: 325; § 570: 342; § 1495: 894; § 1531: 914; $\S 1533$ : 915 , where the Basks are mentioned in different variations as alBaškanš, al-Baškans, al-Bašākisa, al-Waškanš.

${ }^{97} \mathrm{Cf}$. al-Ya 'qūbī, tārīh al-Ya'qūbī, vol. I: 137; Ibn 'Abdu-1-Ḥakam, futūh miṣr wa ahbārihā: 216-17; al-Balādurī, kitāb futūh al-buldān § 270: 231; Ibn Hurradad̄bih, kitāb al-masālik wa-l-mamālik: 90, 153-54; Ibn al-Faq̄īh al-Hamad̄̄n̄̄, muhtașar kitāb al-buldān: 82, 84; Ibn Qūṭiya, tārīh iftitāh al-Andalus: 86-87; al-Ișțahrī, kitāb al-masālik wa-l-mamālik: 43; Ibn Ḥauqal, kitāb șūrat al-arḍ: 111; al-Mas 'ūdī, murū̌g ad-dahab III, 66-75, § 910-20: 145-50 (Arabic ed.), 343-46 (French transl.); Ahbār mağmū'a: 112-13 
European origin and Latin-Christian religiosity.$^{98}$ Although we find a more differentiated picture of Western Europe's ethnic composition, as soon as Muslim geographers writing in Arabic began to distinguish between the more 'modern' Western European peoples at the latest from the thirteenth century onwards, ${ }^{99}$ the 'Franks' were obviously regarded as so representative of Western Europe that the Persian historiographer, Rašìid ad-Dīn (d. 1318), thought it legitimate to identify them with the Romans and to draw a line of continuity between the foundation of Rome and medieval Western Europe at the beginning of the fourteenth century in his extensive historical narrative entitled 'History of the Franks'. ${ }^{100}$ Hence, it is not surprising that medieval Arab-Islamic historiographers had problems understanding Frankish history and wrote comparatively little on the Frankish conversion to Christianity. The first cohesive and only original narrative dealing with the Christianisation of the Franks is provided by al-Mas 'ūdī (d. 956), who had access to a translated Frankish chronicle: ${ }^{101}$

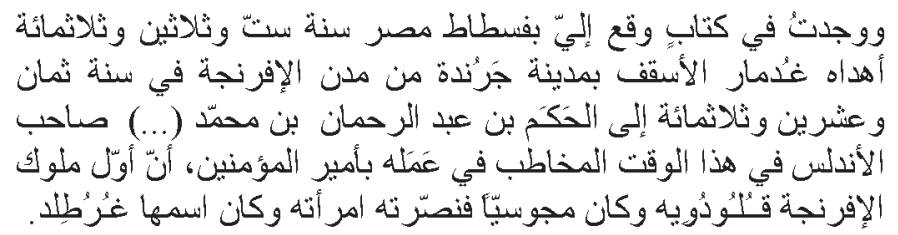

Being in Fusțāt in Egypt in AH 336/939-40 CE, I discovered in a book dedicated by the bishop Godemar of Geronda, one of the cities belonging to the Franks, to al-Hakam bin 'Abdi-r-Raḥmān bin Muhammad (....), currently the

(Arabic ed.), 103-04 (Spanish trans1.); Ibn Ḥayyān, al-muqtabis: 130-31 and Crónica de los emires: 17 (89r); al-Bakrī, kitāb al-masālik wa-l-mamālik, § 567: 340; § 1531: 913.

${ }^{98}$ Cf. Usāma Ibn Munqid, kitāb al-i 'tibār , cap. 8: 132; Ibn al-Ațīr, al-kāmil fì-t-tārīhn, AH 497-98, vol. X: 372, 393; Ibn Haldūn, tārīh, vol. V: 385-87. For further reading on the terminological question: Clément, 'Nommer l'autre: qui sont les Ifranj des sources arabes du Moyen-Âge?'.

${ }^{99}$ Cf. for example: Abū-1-Fidā', taqwīm al-buldān: 187-88, 202 (Arab. ed.), 265-66, 285 (French transl.).

${ }^{100}$ Rašīd ad-Dīn, Frankengeschichte.

${ }^{101}$ al-Mas'ūdī, murū $\breve{g}$ ad-dahab III, 69-72, § 914-16: 147-48 (Arabic ed.), 344-45 (French transl.), trans. by the author.

- The Medieval History Journal, 12, 2 (2009): 431-472 
sovereign of al-Andalus and appealed to as commander of the faithful, that the first Frankish king was Clovis [Qulūdūwīh]. He was pagan [ma ğ $\bar{u} s i y a n]$, but then his wife, whose name was Chrodechild [Gurutild], christianised him.

Later sources offer no alternative or additional information about Frankish religious history if one leaves aside a strange story related by Ibn Hayyān (d. 1076), according to which the Frankish king, Charles (the Bald?), forced the population of his kingdom to bow before a picture of Jesus. ${ }^{102}$ Thus, the narrative of al-Mas 'ūdī, later to be reproduced by al-Bakrī ${ }^{103}$ and an-Nuwairī (d. 1333), ${ }^{104}$ remains the only extant explanation of Frankish conversion, aside from Ibn Haldūn's very cursory remark that Goths and Franks converted to Christianity under the influence of the Romans. ${ }^{105}$ The only other people mentioned in Gaul are the Bretons who are classified as Christians by al-Bakrī. ${ }^{106}$

Even less information is available about the peoples of Northwestern and Northern Europe. Ibn Rustah (d. after 1913) seems to be the only ArabIslamic author until the crusade period who mentions inhabitants of the British Isles, whom he identifies as Christians. ${ }^{107}$ In the thirteenth century, the North African geographer, Ibn Sa 'īd al-Magribī (d. 1286), mentions the Christianisation of the people of Ireland. According to this author, faithfully copied by his later eastern colleague, Abū-l-Fidā' (d. 1331), the people of Ireland had been pagan (ma ğ $\bar{u} s a n)$ but had converted to Christianity under the influence of their neighbours (tumma tanassaru

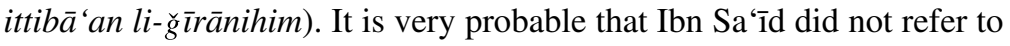
the population of Ireland of the early Middle Ages, whose conversion is

${ }^{102}$ Ibn Ḥayyān, al-muqtabis: 130-31.

${ }^{103}$ al-Bakrī, kitāb al-masālik wa-l-mamālik, § 567: 340.

104 an-Nuwairī, nihāyat al-arab fí funūn al-adab, vol. 15: 286.

${ }^{105}$ Ibn Haldūn, tārīh, vol. IV: 252: 'And when the Romans/Byzantians and the Latins accepted the Christian creed they induced those behind them in the West among the people of the Franks and the Goths to do the same (wa lamma ahada ar-rūm wa-l-laținiyūn limillat an-nașrāniya hamalū man warā' ihim bi-l-mağrib min ahl al-ifran ğa wa-l-qūt 'alaihā fa-dānū bi-hā).'; translated by the author.

106 al-Bakrī, kitāb al-masālik wa-l-mamālik, § 1533: 915.

${ }^{107}$ Ibn Rustah, kitāb a'lāq an-nafisa: 130; cf. Lewis, Muslim Discovery of Europe: 143. Other authors of the pre-crusade era also mention the British Isles, but never its inhabitants; cf. Ibn Hurradadbih, kitāb al-masālik wa-l-mamālik: 231; al-Mas 'ūdī, murūğ ad- $\underline{d} a h a b$ I,180, § 188: 99; Hudūd al- 'ālam § 4,17 C: 58; § 42: 156. 
traditionally attributed to Saint Patrick, but to Viking Ireland. ${ }^{108}$ Finally, information is provided about the Norsemen, known to the Muslims of Spain after several attacks on the Iberian Peninsula in the ninth century. ${ }^{109}$ The Normans' exact geographical origin was still disputed in the midtenth century. ${ }^{110}$ Since they were mostly designated as 'Magians' $(M a g \breve{u} s),{ }^{111}$ a term used generally for pagan peoples, ${ }^{112}$ one may infer that many people believed them to be pagans. ${ }^{113}$ However, diplomatic contact established in the second half of the ninth century must have spread the news that Christianity was slowly spreading among them. A treatise on Western Arabic poetry, by Ibn Dihya (d. 1235), contains the

${ }^{108}$ Ibn Sa 'īd al-Mag̉ibīi, kitāb al-ğ ug rāfiya: 200; Abū-1-Fidā', taqwīm al-buldān: 188 (Arab. ed.), 266 (French transl.). Citing al-'Uḍī, the cosmologist al-Qazwīn̄i, 'atāâr al-bilād'; 34, defines Ireland (Irlānda) as the most important Viking base (laisa li-l-mă̌ $\bar{u} s q \bar{a}$ 'ida

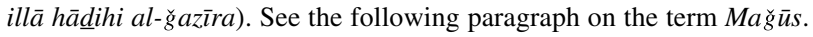

${ }^{109}$ Cf. Ibn Hayyān, Crónica de los emires: 312 (185v-188v).

${ }^{110}$ Cf. al-Mas ‘̄ūī, murū̌̆ a $\underline{d}$ - $\underline{d} a h a b$ I, 364-65, § 404: 193 (Arabic ed.), 147 (French transl.).

${ }^{111}$ Cf. Seippel, A. (ed.). 1928. Rerum normannicarum fontes arabici, Oslo: 1-37. The term 'Mağūs' is used by all medieval Arab-Islamic sources cited in this collection of sources. However, certain other names appear as well, such as 'al-Arman' [Normans] 'alWarank' [Varangians] and 'Rūs'.

${ }^{112} \mathrm{Cf}$. the terms Mă̌̆ $\bar{s}$ and al-Mağūsiya used by al-Bakrī who uses it for paganism in general (al-Bakrī, kitāb al-masālik wa-l-mamālik § 5: 51; § 43: 66; § 72: 80) as well as for the Zoroastrian religion and other pre-Islamic Persian cults $(\S 175$ : 136; $\S 227: 170$; $\S 241: 176$ ), for religious cults in India ( $365: 248)$, among the Alans ( $401: 265)$, the pre-Christian Romans ( $\$ 490: 308$ ), the pre-Christian Franks ( $\$ 567: 340$ ), the Pechenegs ( $\$ 750$ : 445), the king of the Hazar before his conversion to Christianity or Judaism (§ 752: 446f.), the people Burgān (§ 759: 450), the eponym of Crete (§ 811: 482), the nonIslamic population of Sudan ( $\$ 1449: 868)$ and Ghana ( $\$ 1459: 873)$; cf. also al-Mas 'ūdī, murū̌s ad- $\underline{d} a h a b$ II, 326-27, § 747: 48-49 (Arabic ed.), 280 (French transl.). The term is also used for the Franks and the inhabitants of Ireland before their conversion, as has been mentioned earlier.

113 an-Nuwairī, kitāb nihāyat al-arab fi funūn al-adab: 32, defines the 'Mă̌̆ $\bar{u} s$ ' as 'polytheists' (mušrikūn). However, this terminology does not necessarily have to be understood in religious terms and may have served in this case only to oppose righteous Muslims to the Norman aggressors, since the author provides no further information about the Normans' religion. al-Maqarrī, 'naf̣̣ aṭ-țīb min gașni-l-Andalus aț-rațīb': 36, seems to be aware of the terminological difficulties connected with the name 'Măg $\bar{u} s$ '. He mentions a people from the British Isles (Barațaniya) whom he defines as 'Christian Magians' (mağ $\bar{u} s$ 'alā dīn an-nașārā).

- The Medieval History Journal, 12, 2 (2009): 431-472 
travel account of the Muslim ambassador al-Gazāl, who was sent to the Norman king by the Andalusian ruler, 'Abdu-r-Raḥmān II (reigned 822-55). Based on this report, Ibn Dihya provides the following information about the Normans' Christianisation, obviously resorting to a stereotyped description of 'Magian' paganism: ${ }^{114}$

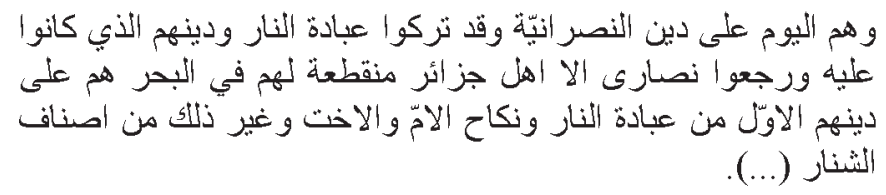

Today they profess the faith of the Christians after leaving behind the cult of fire and the religion they followed. They converted to Christianity except for the people inhabiting a few of their islands that lie isolated in the midst of the sea, who still retained the old religion - the cult of fire, the marriage of mother and sister as well as other disgraceful acts.

If the source is to be trusted, information about Norman conversion had already reached Muslim al-Andalus in the ninth century. The reference is unique, however, neither suggesting that the information was widely diffused nor that it related to the Normans who established polities in northern France and Sicily, later to take part in the crusades: Ibn al-Atīr (d. 1233), for example, believed that Roger I of Sicily was a 'Frank' ${ }^{115}$

More is known about the Christianisation of the peoples of Eastern Europe, probably because their process of conversion took place at a time when Islamic civilisation had already incorporated great parts of the Eastern Mediterranean. The fact that peoples such as the Bulgars belonged to the cultural orbit of Byzantium and not of Latin Christianity may have played a role as well. Ibn Rustah (d. after 913) and the anonymous Persian geographical treatise of the tenth century, Hudūd al-'ālam, mention the

${ }^{114}$ Ibn Dihya, 'kitāb al-muțrib fī aš‘ār al-magrib': 15 and kitāb al-mutrib fì aš ‘ār ahl al-magrib: 140-41, translated by the author; cf. Jacob Arabische Berichte von Gesandten an germanische Fuerstenhöfe aus dem 9. und 10. Jahrhundert: 38; Allen, The Poet and the Spae-Wife: An Attempt to Reconstruct al-Ghazal's Embassy to the Vikings; Dietrich, 'al-Ghazāl'.

${ }^{115}$ Ibn al-Ațīr, al-kāmil fì-t-tārīh , AH 491, vol. X: 272-73; cf. ibid., vol. I: 338. 
Christianisation of Slavic peoples without providing details. ${ }^{116}$ Al-Mas 'ūdī differentiates between pagan Slavs and Christians Slavs following the Jacobite rite. ${ }^{117}$ Al-Bakrī defines the Bulgars as Christian and states that they had translated the gospel into the Slavic language. ${ }^{118}$ On the basis of the tenth century traveller, Ibrāhīm ibn Ya'qūb al-Isrā' '̂lī, al-Bakrī claims that the conversion of the Bulgar king took place during a siege of Constantinople. In an attempt to appease the king, the Byzantine emperor offered presents as well as his daughter in marriage to the Bulgar king, who was eventually converted by his new wife in $922 .{ }^{119}$ Finally, Abū-lFidā' mentions the Christianisation of the Hungarians (al-Hunqar) which he ascribes to their geographical proximity to the Germans (al-Lamāniȳn) ${ }^{120}$

In spite of their vicinity to the Mediterranean and Muslim bases in southern Italy, not much is written about the Christianisation of the peoples inhabiting the Apennine peninsula: the Lombards are mentioned several times, ${ }^{121}$ but not necessarily designated as Christians, as for instance, by Ibn Rustah. ${ }^{122}$ The Venetians (al-Bandaqīs/al-Banādiqa), on the other hand, are declared Christians by the same author, ${ }^{123}$ though no further information is provided. They are counted among the Christian peoples together with the Genoese (al-Ganawiya) by Abū-l-Fidā' ${ }^{124}$ Comparatively, information about the people of Rome is abundant: based on the report of Hārūn bin Yahyāa, a Byzantine captive of the ninth century who may have visited the city, Ibn Rustah even provides some information about the development of Christian traditions among the city's population in the course of Christianisation: ${ }^{125}$

${ }^{116}$ Ibn Rustah, kitāb a 'lāq an-nafisa: 127, mentions that the Slavs converted in the time of the Emperor Basileios; Hudūd al- 'ālam § 42,17: 156.

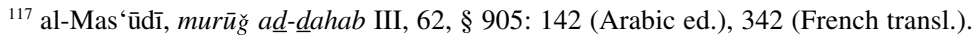

118 al-Bakrī, kitāb al-masālik wa-l-mamālik, § 552: 334-35.

119 Ibid., § 553: 335; cf. Abū-l-Fidā', taqwīm al-buldān: 203, who mentions that the greater part of the Bulgars were Muslims, while some of them still remained Christians.

${ }^{120} \mathrm{Abū}$-1-Fidā', taqwīm al-buldān: 206. It is not clear if he identifies these 'Germans' with the 'Germans' (al-Almān) characterised in his historiographical work as 'one of the largest Christian nations'; cf. Abū-1-Fidā, tārīh $\underline{\text { : }} 168$.

${ }^{121}$ Cf. al-Mas 'ūdī, murūğ ad-dahab III, 76ff., § 920ff.: 151-52 (Arabic ed.), 347-48 (French transl.); al-Bakrī, kitāb al-masālik wa-l-mamālik, § 554: 335; § 558: 337; § 566: 340; § 567: 340; § 571: 342; § 1532: 914.

${ }^{122}$ Ibn Rustah, kitāb a'lāq an-nafìsa: 128.

${ }^{123}$ Ibid.

${ }^{124}$ Abū-1-Fidā', tārīhn: 170.

${ }^{125}$ Ibn Rustah, kitāb a'lāq an-nafìsa: 119, 128-30; translated by the author.

- The Medieval History Journal, 12, 2 (2009): 431-472 


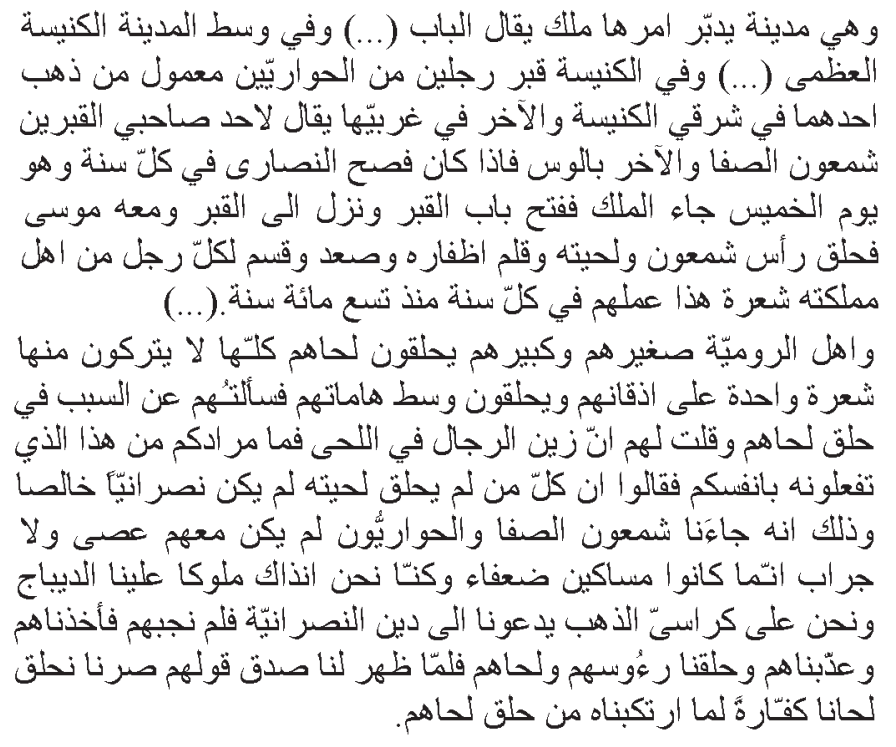

[Rome] is a city administrated by a ruler called the pope $[a l-b \bar{a} b](\ldots)$. In the middle of the city there is the huge church (...). The church contains the graves of two apostles in the West and the East of the church, inlaid with gold. It is said that they belong to Simon Peter and Paul. And every Christian Easter, the ruler comes on Thursday, opens the grave and enters it. Equipped with a razor, he shaves Peter's head and beard and cuts his nails. Coming back he gives one hair to each man in his realm and this is what they have done since 900 years. (...)

The people of Rome, big and small, shave their entire beard, not missing a single hair. They also shave the middle of their head. I asked them concerning the reason for shaving their beard, telling them that the beauty of a man lies in his beard, asking them also concerning the purpose of their behaviour towards themselves. They said: 'Anyone who does not shave in this way cannot be considered a true Christian. And this is the case because Peter and the apostles came to us without staff and sack, since they were weak and poor whereas we were kings at that time, clothed with brocade and sitting on golden chairs. They called us to the Christian religion, but we did not respond to them. Instead we seized and tortured them and shaved their heads and beards. But when it dawned on us that they had spoken the truth, we in turn began to shave our beards because of the sin we had committed when shaving their beards.' 
Ibn Rustah's narrative is later replicated by al-Bakrī. Both provide additional information about religious customs in Rome. ${ }^{126}$ Over the centuries, the pope's rising importance for the regulation of religious and political affairs in Latin Christianity seems to have been acknowledged by Arab-Islamic authors: al-Ya'qūbī refers to him as one of patriarchs present at the council of Nicaea and claims that he ruled the Roman Empire for three years (sic!) some time after the last oecumenical council. ${ }^{127}$ Ibn Rustah (d. after 913) seems to regard the pope as a kind of local sovereign, while al-Bakrī (d. 1094), much better informed, mentions several popes and circumscribes their fields of competence. He refers to unnamed sources which describe the Bishop of Rome as the person who converted Constantine, ${ }^{128}$ mentions another pope called Iohannes [Yuwāniš who allegedly built a new city near Rome ${ }^{129}$ and finally, highlights the pope's influence and supremacy in secular affairs. According to al-Bakrī, Christian rulers had to fall at the pope's feet and kiss them in greeting until the pope allowed them to get up. ${ }^{130}$ Furthermore, he explains the pope's juridical competence in a divorce case involving the Count of Barcelona and a noble lady from Narbonne, correctly describing the effects of excommunication. ${ }^{131}$ The geographer, al-Yāqūt (d. 1229), and the historiographer, Ibn Wāṣil (d. 1298), describe the pope as a religious leader with far-reaching juridical and political powers among European rulers, ${ }^{132}$ whereas the Muslim scholar, Ibn Taymiyya (d. 1328), regarded him important enough to deserve harsh verbal abuse. ${ }^{133}$ Ibn Haldūn (d. 1406) devotes a lengthy passage to the political role of the pope in inner-European affairs, most notably the relationship between pope and

\footnotetext{
${ }^{126}$ al-Bakrī, kitāb al-masālik wa-l-mamālik, § 803 and § 805: 478f.; Ibn Rustah, kitāb a'lāq an-nafìsa: 131-32.

127 al-Ya'qūbī, tārīh al-Ya'qūbī, vol. I: 132-35.

${ }^{128}$ al-Bakrī, kitāb al-masālik wa-l-mamālik, § 498: 312.

${ }^{129} \mathrm{Ibid}$., § 804: 478, may refer to the civitas Leonina, which was constructed by order of Pope Leo IV (sed. 847-55) following the sack of Saint Peter by Saracens in 846.

${ }^{130}$ Ibid., § 803: 478.

${ }^{131}$ Ibid., § 1527: 910-11.

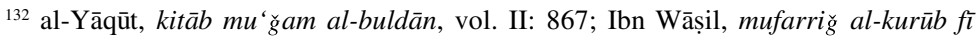
ahbār ban̄̄ Ayyūb, vol. IV: 249.

${ }^{133}$ Ibn Taymīyya, al-ğawāb aṣ-șah̄ih: 183, 190, 208, characterises the pope (al-bāba ar-rūm $\bar{l}$ ) as an idolatrous apostate who performs satanic deeds.
}

- The Medieval History Journal, 12, 2 (2009): 431-472 
emperor. ${ }^{134}$ In his manual on chancery usage, al-Qalqašandī (d. 1418) finally deals with the correct form of adressing letters to the pope, whom he defines as patriarch of the Melchites and equivalent to the caliph, justifying the pope's preeminence over the patriarch of Alexandria with reference to Rome's apostolic tradition. ${ }^{135}$ Thus, from the early tenth century onwards, Arab-Islamic sources-well aware of Rome's claim to apostolic heritage — unconsciously reflect the rise of the papacy, which they seem to regard as the hierarchical pinnacle of European Christianity in the era of the crusades.

\section{Conclusion}

Returning to the question formulated at the beginning of the article, the following conclusions may be drawn. A cohesive narrative that explains the spread of Christianity from the Mediterranean basin to Western, Central, Northern and Eastern Europe, one which at the same time takes into account the great political and social developments in the phase of transition from Antiquity to the early Middle Ages, does not seem to exist in medieval Arab-Islamic literature. This should not imply that Muslims from the earliest times of Islam well into the era of the crusades had no idea about the spread of Christianity. The opposite was the case, as this analysis of several Muslim authors of historiographical, geographical, ethnographical as well as heresiological treatises should have established.

Christianity seems to have interested the first generations of Muslims mainly as a theological phenomenon. But as soon as the emerging ArabIslamic civilisation began to produce more complex and comprehensive forms of historiography from the ninth century onwards, several texts appeared that dealt with the Christianisation of the Roman and the postRoman world. Equipped with information provided in many cases by Oriental Christians, Muslim scholars writing in Arabic began sketching

${ }^{134}$ Ibn Haldūn, $t \bar{a} r \bar{\imath} h$, vol. I: 411-16; vol. II: 297, even mentions the foundation of the papacy at the hands of Peter whom he defines as 'head of the apostles' (kabìr al-hawäriyīn) and 'messenger of the Messiah' (rasūl al-masīh).

135 al-Qalqašandī, kitāb șubh al- 'ašă', vol. V: 472; vol. VIII: 42; cf. Lewis, Muslim Discovery of Europe: 178. 
the different phases of the Roman empire's conversion to Christianity, dealing with the Roman setting of Jesus' life, Roman paganism, the missionary activity of the apostles as well as the hardships that Christians suffered during persecutions. Not as conspicuous, the slow but continuous success of missionary work within Roman society received less attention. The subsequent establishment of Christianity as the dominant religion of the Roman Empire, and especially the conversion of Constantine, were treated extensively. At the same time, Arab-Islamic historiographers began collecting information about the post-Roman peoples of Europe. This information was the product of numerous contacts established between Latin Europe and the Arab-Islamic world during and after the expansion of Islam, providing Muslim historiographers with fragmentary knowledge about the religion and, occasionally, the conversion of the Visigoths, the Franks, the Anglo-Saxons, the people of Ireland, the Norsemen, the Slavs and the Hungarians. In most cases, these references lack a chronological context. Thanks to direct contact as well as to the transmission and translation of important Latin sources, namely, an Arabic version of Orosius as well as of an unknown Frankish chronicle, two post-Roman peoples - the Visigoths and the Franks-clearly emerge in Muslim narratives, whereas the religion and Christianisation of other peoples pertaining to the migration period of the fourth to the sixth century such as the Alans, Sueves, Burgundians, Vandals, etc., was completely ignored.

The developments that set the stage for the emergence of LatinChristian Europe-notably Roman hegemony in great parts of Western Europe as well as the transformation of the Roman Empire during the so-called era of migrations which led to the establishment of RomanoGermanic successor states in Western Europe-only seem to have been understood to a certain degree when the above-mentioned Latin sources slowly and cautiously made their influence felt, among others, in the works of al-Mas 'ūdī (d. 956), al-Bakrī (d. 1094), Ibn al-Atīir (d. 1233) and Ibn Haldūn (d. 1406). Lacking knowledge about the West in the period between the fourth and the sixth centuries, knowledge that was neither provided by Oriental Christians nor by superficial (on an intellectual scale) contacts with neighbouring peoples, has to be regarded as an important missing link that impeded Arab-Islamic historiographers from drawing a larger picture of the Christianisation of post-Roman Latin Europe. Without this knowledge, an understanding of the dependent processes of Christianisation in Northern and Central Europe, regions

- The Medieval History Journal, 12, 2 (2009): 431-472 
lying far beyond the zones of contact connecting the Arab-Islamic world and Latin-Christian Europe, was not possible, especially in the light of the complicated ethnic, political and religious changes that occurred in medieval Europe. The only clear line of continuity to be found in ArabIslamic historiography concerns the papacy and the people of Rome, whose history was clearly linked to Rome's imperial past.

If we imagine asking a Middle Eastern Muslim of the crusading era, how the European aggressors who had just appropriated his land had turned Christian, we would have to reckon with different possible answers. Depending on the respective Muslim's education in universal history, he would - with great likelihood-be able to refer to the Christianisation of the Roman Empire at the hands of Constantine, probably name a few Christian peoples of Western Europe and most probably mention the pope in Rome-the medieval institution clearly linked to the Roman past from an outside perspective, a link that was fortified, as the anecdote recounted by Cafaro, cited at the beginning of this article proves, by the crusaders themselves. In view of the facts established, it is rather hard to imagine that the Muslim mentioned would be capable of explaining the intricacies of the Christianisation of Western Europe's more recent peoples. Looking back on the results of this article as just presented, such an explanation would correspond to the account furnished by Ibn Haldūn (d. 1406) in his Muqaddima - a rough sketch, possibly written without a library at hand ${ }^{136}$ and much less detailed than the more extensive but disrupted treatment of the subject in the following volumes of his great universal history. Ibn Haldūn's rough sketch seems rather representative of what a well-educated Muslim of the late crusade era would have known about the Christianisation of Europe, that is, quite a lot about the Romans, quite a lot about the pope, but relatively little about the period that lay between the Christian Roman Empire of late Antiquity and the papacy of the crusader times, a period that witnessed the Christianisation of Germanic warrior elites and several later European peoples. ${ }^{137}$

${ }^{136}$ This is what Issawi, 'Ibn Khaldun on Ancient History': 62, believes, searching for an explanation between the striking discrepancies between the Muqaddima and the rest of his universal history, the Kitāb al-'ibar.

${ }^{137}$ Ibn Haldūn, tārīh, vol. I: 411-16; Ibn Khaldūn, al-Muqaddimah VI, 18, vol. I: 476-81. 


\section{References}

\section{Primary Sources}

Abū 'Īsā al-Warrāq. 2002. Early Muslim Polemic Against Christianity: Abū 'T̄sā al-Warrāq's 'Against the Incarnation' [kitāb ar-radd 'alä-t-tat lițt]. Edited and translated by D. Thomas, Cambridge.

Abū-l-Fidā'. 1831. tārīh = Abulfedae Historia Anteislamica arabice. Edited and translated by H.O. Fleischer, Leipzig.

1840. taqwīm al-buldān. Edited by M. Reinaud, Paris.

Ahbār mă̆ḡ̄' $a$. 1867. Edited and translated by Don Emilio Lafuente y Alcántara, Madrid. al-Bakrī. 1992. kitāb al-masālik wa-l-mamālik. Edited by A. van Leuwen and A. Ferre, Tunis.

al-Balādurī. 1866 (repr. 1992). kitāb futūh al-buldān. Edited by Michael de Goeje, Leiden and Frankfurt.

al-Bīrūn̄i. 1923. ațār al-bāqiya 'an al-qurūn al-hāliya. Edited by E. Sachau, Leipzig.

al-Buhari. 2007. Șāhih al-Buārī. L'Authentique d'al-Bukhārī, vol. I. Edited and translated by O. Houdas, W. Marçais and C. Pabiot, Paris.

al-Imām al-Qurțubī. 1980. kitāb al-i ' lām bi-mā fì dīn an-nașāra min al-fasād wa-l-auhām

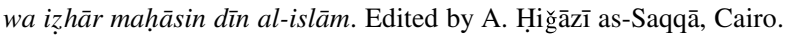

al-Iștahrīi. 1927. kitāb al-masālik wa-l-mamālik. Edited by M.J. de Goeje, Leiden.

al-Maqqarī, 'nafh aṭ-ṭīb min gusn al-Andalus ar-rațib', in A. Seippel (ed.), Rerum Normannicarum fontes arabici, Oslo.

al-Mas'ūdi, 1894. kitāb at-tanbīh wa-l-išrāf. Edited M.J. de Goeje, Leiden.

1962-97. Les prairies d'or. Translated by Barbier de Meynard, Pavet de Courteille and Charles Pellat, 5 vols, Paris.

1966-79. murūğ ad-dahab wa ma 'ādin al-ğauhar. Edited by Barbier de Meynard,

Pavet de Courteille and Charles Pellat, 7 vols, Beirut.

al-Qalqašandī. 1915. kitāb șubhal- 'ašā', 14 vols, Cairo.

al-Ya'qūbī. 1964. tārīh al-Ya'qūbī. Edited by Muhammad Șādiq, 3 vols, Nağaf.

al-Yāqūt. 1866-70. kitāb ти' '̆am al-buldān. Edited by F. Wüstenfeld, 6 vols, Leipzig. an-Nuwairī. 1923-1955. nihāyat al-arab fì funūn al-adab, 18 vols, Cairo.

Annales Mettenses priores. 1905. Edited by B. de Simson, Monumenta Germaniae Historica, Scriptores rerum Germanicarum in usum scholarum editi 10, Hannover.

Antoninus Placentinus. 1965. Itinerarium. Edited by P. Geyer, Corpus Christianorum series Latina (CCL) 175, Turnhout.

aṭ-Ṭabarī. 1960-66. tārīh ar-rusul wa-l-mulūk. Edited by M. Abū-l-Faḍl Ibrāhīm, 10 vols, Cairo.

Bernardus monachus. 1852. Itinerarium factum in loca sancta, Migne Patrologia Latina, vol. 121, Paris.

Cafaro. 1863. Annales Ianuenses. Edited by G.H. Pertz, Monumenta Germaniae Historica, Scriptores 18, Stuttgart.

Chronica hispana. 1894 (repr. 1961). Edited by Th. Mommsen, Monumenta Germaniae Historica, Auctores Antiquissimi 11, Berlin.

- The Medieval History Journal, 12, 2 (2009): 431-472 
Chronicon Moissiacense. 1876. Edited by G.H. Pertz, Monumenta Germaniae Historica, Scriptores I, Hannover.

Codex Carolinus. 1892. Edited by W. Gundlach, Monumenta Germaniae Historica epistolae tomus III: Merowingici et Karolini aevi I, Berlin.

Crónica del moro Rásis. 1974. Edited by Diego Catalan et María Soledad de Andrés, Madrid.

Eulogius. 1973. Memoriale Sanctorum. Edited by I. Gil, Corpus Scriptorum Muzarabicorum II, Madrid.

Eusebius. 1913. Vita Constantini. Translated by J. Pfättisch, Bibliothek der Kirchenväter 9, Munich.

Fredegar Continuator. 1888. Chronicarum continuationes. Edited by B. Krusch, Monumenta Germaniae Historica, Scriptores rerum Merovingicarum 2, Hannover.

Gesta abbatum Fontanellensium § 9. 1886. Edited by S. Loewenfeld, Monumenta Germaniae Historica, Scriptores rerum Germanicarum in usum scholarum editi 28, Hannover.

Gregorius Turonensis. 1951. Libri decem. Edited by B. Krusch and W. Levison, Monumenta Germaniae Historica, Scriptores rerum Merowingicarum 1, 1, Hannover.

- 1969. In gloria confessorum. Edited by B. Krusch, Monumenta Germaniae Historica, Scriptores rerum Merowingicarum 1, 2, Hannover.

Hafs le Goth. 1994. Le Psautier mozarabe de Hafs le Goth. Edited and translated by Marie-Thérèse Urvoy, Toulouse.

Hieronymus. 1996. ep. 129. Edited by I. Hilberg, Corpus Scriptorum ecclesiasticorum latinorum, 56, 1, Vienna.

Hudūd al-'ālam-The Regions of the World. A Persian Geography. 1937. Translated and comm. by V. Minorsky, Oxford.

Ibn 'Abdu-l-Hakam. 1999. futūḥ mișr wa ahbārihā. Edited by Charles C. Torrey, Cairo. Ibn al-Atîr. 1965-66. al-kāmil fì-t-tārīh . Edited by C.J. Tornberg, 12 vols, Beirut.

Ibn al-Faqīh al-Hamadānī. 1885 (repr. 1967). muhtaṣar kitāb al-buldān. Edited by Michael de Goeje, Leiden.

Ibn al-Qūṭiya. 1989. tārīh iftitāḥ al-Andalus. Edited by Ibrāhīm al-Abyārī, Beirut and Cairo.

Ibn Diḥya. 1896/1928. 'kitāb al-muțiib fĩ aš‘ār ahl al-mag̉rib', in A. Seippel (ed.), Rerum Normannicarum fontes arabici, Oslo.

1955. kitāb al-muțrib fĩ aš ‘̄ar ahl al-mag̀rib. Edited by Ibrāhīm al-Abyārī, Ḥāmid 'Abdu-1-Mağ̄id and Aḥmad Aḥmad Badawī, Cairo (??).

Ibn Habīb. 1991. kitāb at-tārīh. Edited by Jorge Aguadé, Madrid.

Ibn Haldūn. 1956-66. tārīh, 5 vols, Beirut.

Ibn Hauqal. 1938. kitāb șūrat al-arḍ, Edited by J.H. Kramers, Leiden.

Ibn Ḥayyān al-Qurțubī. 1973. al-muqtabis min abnā' ahl al-Andalus. Edited by Maḥmūd 'Alī Makkī, Beirut.

1979. al-muqtabis min abnā' ahl al-Andalus [V]. Edited by Pedro Chalmeta and Federico Corriente, Madrid.

Ibn Ḥayyān. 2001. Crónica de los emires Alhakam I y 'Abdarraḥmān II [Al-muqtabis II-1]. Translated and comm. by Mạ̣mūd Alī Makkī y Federico Corriente, Zaragoza.

The Medieval History Journal, 12, 2 (2009): 431-472 
Ibn Ḥazm. 1929. kitāb al-fișal fì-l-milal wa-l-ahwwā'wa-n-niḥal. Abenházam de Córdoba y su historia crítica de las ideas religiosas. Comm. and translated by Miguel Asín Palacios, 5 vols, Madrid.

Ibn Hišām. 1955. as-sīra an-nabawiya. Edited by Muștafā as-Saqā, Ibrāhīm al-Abyārī and 'Abdu-1-Hafīz Šalbī, vol. I, Cairo.

Ibn Hurradadbih. 1889. kitāb al-masālik wa-l-mamālik. Edited by M. de Goeje, Leiden.

Ibn 'Id̄ārī al-Marrākušī. 1980. kitāb al-bayān al-mug̀rib. Edited by G.S. Colin et É. LéviProvençal, 4 vols, Beirut.

Ibn Khaldūn. 1958. The Muqaddimah. An Introduction to History. Translated by Franz Rosenthal, 3 vols, New York.

Ibn Rustah. 1892. kitāb a 'lāq an-nafìsa. Edited by M.J. de Goeje, Leiden.

Ibn Sa'īd al-Mag̉ribī. 1970. al-ğuggrāfiya. Edited by Ismāīl al-'Arabī, Beirut.

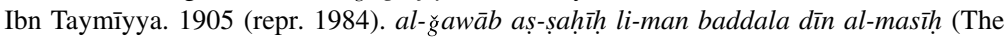
Correct Answer to Those Who Changed the Religion of the Messiah). Translated by T.F. Michel, Cairo and New York.

Ibn Wāṣil. 1953-77. Mufarriğ al-kurūb fì ahbār ban̄̄ Ayyūb. Edited by Gamāl ad-Dīn ašŠayāl, Hassanain Muhammad Rabī' and Sa 'īd 'Abdu-1-Fattāh 'Ašūr, 5 vols, Cairo.

Iohannis abbas s. Arnulfi. 1841. Vita Iohannis Gorziensis § 128. Edited by G.H. Pertz, Monumenta Germaniae Historica, Scriptores IV, Hannover.

Iohannes Biclarensis. 1894 (repr. 1961). Chronica. Edited by Th. Mommsen, Monumenta Germaniae Historica, Auctores Antiquissimi 11, Berlin.

kitāb Hurūšiyūšs. Traducción árabe de las Historiae adversus paganos de Orosio. 2001. Edited by Mayte Penelas, Madrid.

Lactantius. 1954. De mortibus persecutorum. Edited and translated by J. Moreau, Sources Chrétiennes 39, Paris.

Martinus papa. 1851. ep. 14 ad Theodorem, Migne Patrologia Latina 87, Paris.

Rašīd ad-Dīn. 1977. Frankengeschichte. Translated by K. Jahn, Vienna.

Șā‘id al-Andalusī. 1985. kitāb țabaqāt al-ummam. Edited by Ḥayāt Bū'alwān, Beirut. 1991. Science in the Medieval World: 'Book of the Categories of Nations'. Translated by S. Salem and A. Kumar, Austin, 1991.

Seippel, A. (ed.). 1896/1928. Rerum Normannicarum fontes Arabici, Oslo.

Shahrastani. 1993. Livre des religions et des sects. Translated and comm. by J. Jolivet and G. Monnot, 2 vols, UNESCO.

Usāma bin Munqid. 1930. kitāb al-i'tibār. Edited by Philip K. Hitti, Princeton.

Victor Tonnenensis. 1894 (repr. 1961). Chronica. Edited by Th. Mommsen, Monumenta

Germaniae Historica, Auctores Antiquissimi 11, Berlin.

\section{Secondary Literature}

ad-Dūrī, 'Abdu-l-'Azīz. 2005. 'naš' at at-tārīh 'ind al-'arab wa tațawwuruhu hilāl al-qurūn at-talāta al-ūlā li-1-hiğra', in A. ad-Dūrī (ed.), naš' at 'ilm at-târīh 'ind al- 'arab, Beirut. al-Ḥağğî. 2004. 'Abdu-r-Raḥmān 'Alī', in 'alāqāt al-diblūmāsīya al-andalusiya ma' Úrubbāal-garbiya hilāl al-muddat al-ummawiya (138-366 AH/755-976AD), Abū Zabbī. Allen, W.E.D. 1960. The Poet and the Spae-Wife: An Attempt to Reconstruct al-Ghazal's Embassy to the Vikings, London.

- The Medieval History Journal, 12, 2 (2009): 431-472 
Antequera, Luis. 2006. Jesús en el Corán, Madrid.

Arsel, Ilhan. 2006. Juden und Christen im Koran, Norderstedt.

aš-Šaih. 1981. 'Muhammad Murs̄̄', in dawlat al-faranğa wa 'alāqātihā bi-l-umawiyȳ̄n fì-l-Andalus: hattā awāhir al-qarn al- 'āšir al-mīlād̄̄ (138-366 AH/755-976 AD), Alexandria.

Bachmann, Ludwig. 1925. Jesus im Koran, Frankfurt.

Badawī, Aḥmad. 1982. Awrūsiyūs. tārīh al-'àlam, Beirut.

Baus, Karl. 1962. 'Von der Urgemeinde zur frühchristlichen Großkirche', in Hubert Jedin, Handbuch der Kirchengeschichte, Vol. I, Frankfurt a. M.

Bazargan, Mehdi. 2006. Und Jesus ist sein Prophet: Der Koran und die Christen, Munich.

Behloul, Samuel-Martin. 2002. Ibn Hazms Evangelienkritik. Eine methodische Untersuchung, Leiden.

Borgolte, Michael. 1976. Der Gesandtenaustausch der Karolinger mit den Abbasiden und mit den Patriarchen von Jerusalem, München.

Christys, Ann. 2002. Christians in al-Andalus (711-1000), Richmond.

Çinar, Hüseyin İlker. 2007. Maria und Jesus im Islam: Darstellung anhand des Korans und der islamischen kanonischen Tradition unter Berücksichtigung der islamischen Exegeten, Wiesbaden.

Clément, François. 2009. 'Nommer l'autre: qui sont les Ifranj des sources arabes du MoyenÂge?', in Isabelle Reck and Edgard Weber (eds), recherches 02. de mots en maux: parcours hispano-arabe, Strasbourg: 89-105.

Donner, Fred M. 1998. Narratives of Islamic Origins. The Beginnings of Islamic Historical Writing, Princeton.

Dietrich, A. 1998. 'al-Ghazāl', in Johannes Hoops (ed.), Reallexikon der germanischen Altertumskunde, Vol. 12, Berlin: 64-66.

Dumézil, Bruno. 2006. Les racines chrétiennes de l'Europe. Conversion et liberté dans les royaumes barbares, V'-VIII ${ }^{e}$ siécles, Paris.

Gams, Pius Bonifacius. 1956. Die Kirchengeschichte von Spanien, Vol. I, Graz.

Graf, Georg. 1944. Geschichte der christlichen arabischen Literatur, Vol. I., Città del Vaticano.

Harnack, Adolf von. 1924. Die Mission und Ausbreitung des Christentums in den ersten drei Jahrhunderten, Leipzig.

Heinzelmann, Martin. 2003. 'La réécriture hagiographique dans l'œuvre de Grégoire de Tours', in Martin Heinzelmann and Monique Goullet (eds), La réécriture hagiographique dans l'Occident médiéval. Transformations formelles et idéologiques, Sigmaringen: $15-70$.

Henninger, J. 1961. 'Arabische Bibelübersetzungen vom Frühmittelalter bis zum 19. Jh.', Neue Zeitschrift für Missionswissenschaft, vol. 17: 201-23.

Husain, Gassān 'Azīz. 2002. Waraqa Ibn Naufal: mubaššir ar-rasūl. 'aṣruhū, hạāatuhū, ši $r u h \bar{u}$, Beirut.

Issawi, Charles. 1998. 'Ibn Khaldun on Ancient History. A Study in Sources', in Charles Issawi (ed.), Cross-Cultural Encounters and Conflicts, New York: 51-78.

Jacob, Georg. 1927. Arabische Berichte von Gesandten an germanische Fuerstenhoefe aus dem 9. und 10. Jahrhundert. Berlin. 
Jourdan, François, Jacques de Saroug, 'Abd Allāh Ibn 'Abbās (eds). 2001. La tradition des Sept Dormants: une rencontre entre chrétiens et musulmans, Paris.

Kahle, P. 1904. Die arabischen Bibelübersetzungen, Leipzig.

Kedar, Benjamin Z. 1988. Crusade and Mission, Princeton.

Khalidi, Tarif. 1996. Arabic Historical Thought in the Classical Period, Cambridge.

2001. The Muslim Jesus: Sayings and Stories in Islamic literature, Cambridge.

König, Daniel. 2006. 'Der Nutzen von Außenperspektiven. Das europäische Mittelalter aus moderner arabischer Perspektive', in Stephan Conermann and Marie-Christine Heinze (eds), Bonner Islamwissenschaftler stellen sich vor, Hamburg: 197-242.

2008. Bekehrungsmotive. Untersuchungen zum Christianisierungsprozess im römischen Westreich und seinen romanisch-germanischen Nachfolgern (4.-8. Jh.), Husum.

Levi della Vida, Giorgio. 1954. 'La Traduzione araba delle storie di Orosio', Al-Andalus, vol. 19: 257-93.

Levison, Wilhelm. 1948. 'Die Anfänge rheinischer Bistümer in der Legende', in Wilhelm Levison (ed.), Aus rheinischer und fränkischer Frühzeit, Düsseldorf: 7-27.

Lewis, Bernard. 2001. The Muslim Discovery of Europe, New York.

Ljamai, Abdelilah. 2003. Ibn Hazm et la polémique islamo-chrétienne dans l'histoire de l'islam, Leiden.

MacMullen, Ramsay. 1984. Christianizing the Roman Empire (A.D. 100-400), New Haven.

Menéndez-Pidal, Ramón (ed.). 1935. Historia de España, vol. II/2: La España romana, Madrid.

Millet-Gérard, Dominique. 1984. Chrétiens mozarabes et culture islamique dans l'Espagne des VIIIe-IXe siècles, Paris.

Molina, Luís. 2000. 'Tudmīr', in Encyclopédie de l'Islam (nouvelle édition), vol. X: 628-30.

Padberg, Lutz E. von. 1995. Die Christianisierung Europas im Mittelalter, Stuttgart.

Parrinder, Edward Geoffrey. 2003. Jesus in the Qur'ān, Oxford.

Praet, Danny. 1992-93. 'Explaining the Christianization of the Roman Empire. Older Theories and Recent Developments', Sacris Erudiri, vol. 33: 5-119.

Qazzī, Gūzif. 2002. Nașārāa al-Qur'ān wa-masīḥ̄yūhu, Dīyār 'Aql. 2006. Masīh al-Qur'ān wa-masīh al-muslimīn, Dīyār 'Aql.

Rotter, Ekkehard. 1986. Abendland und Sarazenen, Berlin.

Schoeler, Gregor. 1996. Charakter und Authentie der muslimischen Überlieferung über das Leben Mohammeds, Berlin and New York.

2008. The Genesis of Literature in Islam. From the Aural to the Read, Cairo.

Shepard, William. 1996. Sayyid Qutb and Islamic Activism. A Critical Study and Translation of Social Justice in Islam, Leiden.

Talbi, Mohamed. 1956. 'Intérêt des oeuvres juridiques traitant de la guerre pour l'historien des armées médiévales ifrikiyennes', Cahiers de Tunisie 15, vol. 4, 1er trimestre: 289-93.

Wolf, Kenneth Baxter. 1988. Christian Martyrs in Muslim Spain, Cambridge.

Zwemer, Samuel M. 1912. The Moslem Christ. An Essay on the Life, Character, and Teachings of Jesus Christ According to the Koran and Orthodox Tradition, Edinburgh. 